\title{
PROJECT GASBUGGY: RADIATION CONTAMINATION CLEARANCE REPORT
}

\author{
by \\ Eberline Instrument Corporation \\ Santa Fe, New Mexico 87501
}

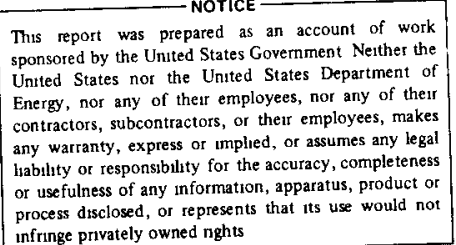

Date Published - June 27, 1979

Prepared for

U.S. DEPARTMENT OF ENERGY

NEVADA OPERATIONS OFFICE

UNDER CONTRACT NO. ET-78-C-08-1582 


\section{DISCLAIMER}

This report was prepared as an account of work sponsored by an agency of the United States Government. Neither the United States Government nor any agency Thereof, nor any of their employees, makes any warranty, express or implied, or assumes any legal liability or responsibility for the accuracy, completeness, or usefulness of any information, apparatus, product, or process disclosed, or represents that its use would not infringe privately owned rights. Reference herein to any specific commercial product, process, or service by trade name, trademark, manufacturer, or otherwise does not necessarily constitute or imply its endorsement, recommendation, or favoring by the United States Government or any agency thereof. The views and opinions of authors expressed herein do not necessarily state or reflect those of the United States Government or any agency thereof. 


\section{DISCLAIMER}

Portions of this document may be illegible in electronic image products. Images are produced from the best available original document. 


\section{PROJECT GASBUGGY RADIATION CONTAMINATION CLEARANCE REPORT}

by

Eberline Instrument Corporation

Santa Fe, New Mexico 87501

Date Published - June 27, 1979

Prepared for

U.S. DEPARTMENT OF ENERGY

NEVADA OPERATIONS OFFICE

UNDER CONTRACT NO. ET-78-C.08-1582 


\begin{abstract}
NOTICE
This document was prepared as an account of work sponsored by the United States Government. Neither the United States nor the United States Department of Energy, nor any of their employees, nor any of their contractors, subcontractors, or their employees, makes any warranty, expressed or implied, or assumes any legal liability or responsibility for the accuracy, completeness, or usefulness of any information, apparatus, product, or process disclosed, or represents that its use would not infringe privately owned rights.
\end{abstract}

REPRODUCED IN THE UNITED STATES OF AMERICA

Available from

National Technical Information Service

U.S. Department of Commerce

5285 Port Royal Road

Springfield, VA 22161

Price: Printed Copy $\$ 4.50$ Microfiche $\$ 3.00$ 


\section{TABLE OF CONTENTS}

NOTICE $\ldots \ldots \ldots \ldots \ldots \ldots$

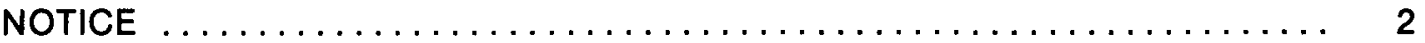

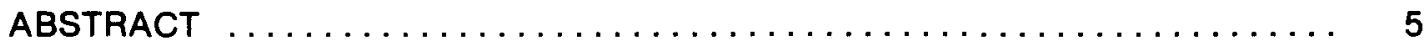

Narrative Report with Conclusion

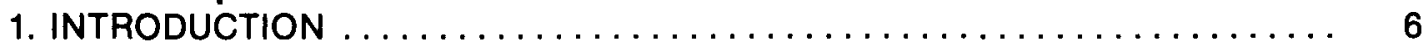

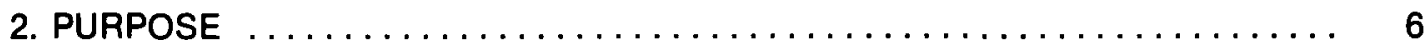

3. DISPOSAL OF RADIOACTIVE MATERIAL $\ldots \ldots \ldots \ldots \ldots \ldots \ldots \ldots \ldots \ldots$

4. PERSONNEL MONITORING AND BIOASSAY $\ldots \ldots \ldots \ldots \ldots \ldots \ldots \ldots \ldots$

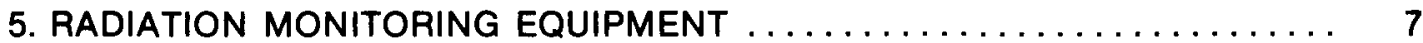

6. PLUGGING AND ABANDONMENT ACTIVITIES $\ldots \ldots \ldots \ldots \ldots \ldots \ldots \ldots \ldots 7$

7. DECONTAMINATION ACTIVITIES $\ldots \ldots \ldots \ldots \ldots \ldots \ldots \ldots \ldots \ldots \ldots \ldots \ldots \ldots \ldots$

8. SITE SAMPLING AND SURVEY ACTIVITIES $\ldots \ldots \ldots \ldots \ldots \ldots \ldots \ldots \ldots$

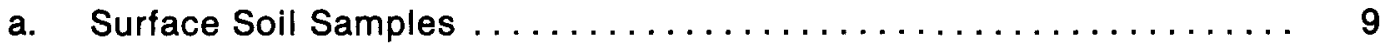

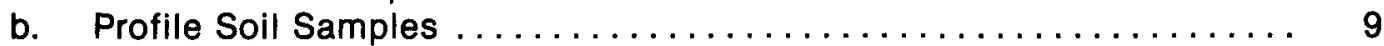

c. Operational Soil Samples ......................... 10

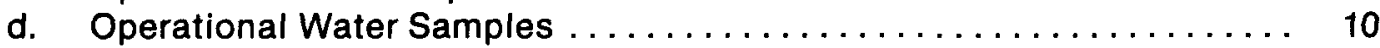

e. Beta Gamma Survey ........................... 11

f. Additional Analytical Capability ...................... 11

g. Vegetation Samples $\ldots \ldots \ldots \ldots \ldots \ldots \ldots \ldots \ldots \ldots \ldots \ldots \ldots \ldots \ldots$

h. Quality Control ................................. 11

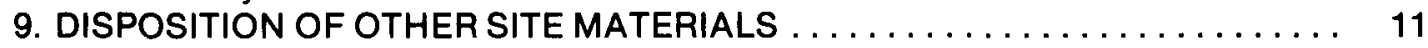

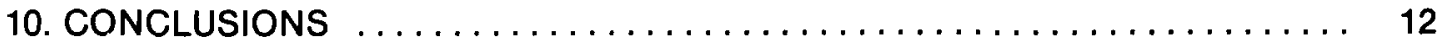




\section{LIST OF TABLES}

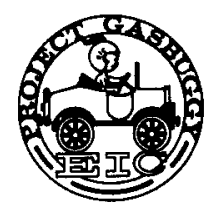

TABLE 1

TABLE 2

TABLE 3

TABLE 4

TABLE 5

TABLE 6

TABLE 7

TABLE 8
Surface Soil Samples ........................ 13

Profile Sample Sets . ........................ 14

Post Operational Surface Soil Samples ............... 22

Determination of ${ }^{90} \mathrm{Sr}$ and ${ }^{238} /{ }^{239} \mathrm{Pu}$ in Soil Samples . . . . . . . . . 24

Gamma Emitting Isotopes in Site Samples . . . . . . . . . . 26

Environmental Vegetation Sample Results ............. 28

List of Barrels \& Contents Sent to NTS . . . . . . . . . . . 29

Site Clearance Criteria ........................... 30

\section{LIST OF FIGURES}

FIGURE 1

Project Gasbuggy Site Location Map

31

FIGURE 2

Project Gasbuggy Pre-Cleanup Status Map

Ground Zero Area.......................... 32

FIGURE 3

FIGURE 4

FIGURE 5

FIGURE 6

Project Gasbuggy Post-Cleanup Status Map

Ground Zero Area......................... 33

Sampling Locations .......................... 34

Profile Soil Sample Locations ................... 35

Tritium Activity vs Depth - Profile Hole \#1

and $\# 1$ Rerun $\ldots \ldots \ldots \ldots \ldots \ldots \ldots \ldots \ldots \ldots \ldots \ldots \ldots \ldots \ldots$

FIGURE $7 \quad$ Tritium Activity vs Depth - Profile Holes \#22 \& \#23 . . . . . . . 37

FIGURE $8 \quad$ Tritium Activity vs Depth - South of Flare Stack . . . . . . . . . 38

FIGURE $9 \quad$ Tritium Activity vs Depth - North of Flare Stack........... 39

FIGURE 10 Post Operation Surface Soil Sampling Locations ........... 40

FIGURE 11 Location of Non-Radioactive On-Site Burials ............. 41 


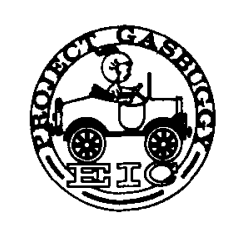

\begin{abstract}
Project Gasbuggy was the first U.S. underground nuclear experiment for the stimulation of low-productivity natural gas reservoirs.

This report describes the radiological health and safety operations required for site cleanup and restoration to return the site to approximately its original condition. These operations were conducted from August through September of 1978. All equipment on site which was radiologically contaminated during previous gas production test activities was steam decontaminated to well below applicable release criteria and was released for unrestricted use.

The radiological site restoration operations were successful. The radiological area survey indicates that no radiation levels above ambient background remain on-site. Only tritium $\left({ }^{3} \mathrm{H}\right)$ in quantities well below criteria remains in the on-site soil as determined by soil sampling.

The quality of the natural environment was improved by the removal of numerous man-made objects, the removal and controlled disposal of the site contaminants, and the sealing from possible release to the environment of a deep underground radiological source.
\end{abstract}




\section{INTRODUCTION}

Project Gasbuggy was a cooperative research effort undertaken between EI Paso Natural Gas Company (EPNG) and the U.S. Atomic Energy Commission (AEC), now part of the Department of Energy (DOE), and the Department of the Interior's Bureau of Mines with technical assistance from the Lawrence Radiation Laboratory (LRL), now Lawrence Livermore Laboratory (LLL).

Early in 1967 exploration wells GB-1 and GB-2 were completed, and the San Juan Basin site in northwest New Mexico was accepted. (See Figure 1) The nuclear emplacement hole GB-E was started in June of 1967. On December 10, 1967 a 29-kiloton nuclear explosive was detonated at a depth of 4,240 feet in the lowpermeability Pictured Cliffs sandstone formation.

After reentry drilling six major production tests were conducted. Two took place in 1968 , three in 1969, and the last one 1973. The reentry well, GB-ER, has been shut in since the 1973 productivity test, with only pressure monitoring being conducted and small gas samples periodically taken since that time.

\section{PURPOSE}

The purpose of this report is to identify the extent of radioactive contamination of site property pursuant to the requirements of ERDA Manual Appendix 5301, to summarize all radiological activities during site restoration and to describe final site radiological conditions.

\section{DISPOSAL OF RADIOACTIVE MATERIAL}

No burial of radioactive material was made at the Gasbuggy site during the cleanup operation.

Approximately 60.5 barrels of tritium contaminated water and sludge at an average of $1439 \mathrm{pCi} / \mathrm{ml}$ and 7.3 barrels of tritium contaminated water and sludge at an average of $350 \mathrm{pCi} / \mathrm{ml}$ were pumped from the produced water storage tank which is referred to throughout this document as the "Red Tank" and decon sump, respectively, and injected into the GB-ER cavity before the reentry well was plugged. The tubing and annulus were then flushed with 3 annulus volumes of $\mathrm{H}_{2} \mathrm{O}$. The total tritium content of the injected fluid was $18.7 \mathrm{mCi}$. The water did not contain other radioactive isotopes above detection limits except naturally occurring radioactive elements. (See Tables 4 and 5.)

Some 400 objects were steam decontaminated, measured for radioactive contamination and found to be within the release limit criteria for unrestricted use. After steam cleaning no material exceeded the release limit for unrestricted use (see Table 8 for release limits).

Items of equipment having inaccessible interiors were flushed with steam until the exiting flush water and accessible area swipes of the item were below release limits. As an additional check, specified in NVO 195, (reference page 30), water was poured through various tubular goods and the exiting water sample was analyzed for tritium. None of these samples approached the $5,000 \mathrm{dpm} / \mathrm{ml}(2250 \mathrm{pCi} / \mathrm{ml})$ arbitrary limit set as a double check. The $5,000 \mathrm{dpm} / \mathrm{ml}$ limit was not selected as a release limit criterion but on the basis that if the item were used as unrestricted radiologically, "clean" water contacting the surfaces of the item would be unlikely to ever exceed the 10 CFR 20 or State of New Mexico Concentration Guides for water in unrestricted areas $(3000$ $\mathrm{pCi} / \mathrm{ml}$ ). Experience at other sites similar to Gasbuggy had shown that while an item may be cleared radiologically immediately after cleaning, in some cases tritium would be detected after a watering delay of 12-24 hours. In addition these items could not be 
cleared under the ANSI Standard because of the inaccessible surfaces and the above discussed test was devised to meet the "case by case basis" requirement as specified in the Standard.

One hundred seventy-five barrels of low level tritium contaminated water from the steam decontamination operation accumulated in the "Red Tank" after the GB-ER wellbore was sealed. The water was subsequently disposed of by vaporization to the atmosphere using the steam generator. The tritium level in this water ranged from 14.7 $\mathrm{pCi} / \mathrm{ml}$ to $43.7 \mathrm{pCi} / \mathrm{ml}$, and a total of $1.31 \mathrm{mCi}$ was released to the atmosphere over a period of 25 days in September 1978. During the water vaporization and steam decontamination activities, air moisture samples were collected by molecular sieve units around the site (see Figure 4 for location). All of the moisture samples thus collected were less than the lower limit of detection (LLD) for tritium air moisture.

All unused portions of contaminated water and soil samples were placed in a single radioactive waste barrel to be shipped to the Nevada Test Site (NTS) for disposal.

A total of 10 barrels of materials, either known to be slightly radioactive or difficult to make a determination of radioactive content, were sealed, externally steam cleaned, and labeled for shipment as low level radioactive waste. Dry materials were barreled intact and all fluids were mixed with diatomaceous earth and cement before packaging. See Table 7 for a list of barrels and their contents. Nuclides other than tritium and naturally occurring isotopes were not found to be present. The total tritium content of all 10 barrels was less than $1 \mathrm{mCi}$.

\section{PERSONNEL MONITORING AND BIOASSAY}

All personnel participating in Gasbuggy cleanup were required to wear thermoluminescent dosimeter (TLD) badges and to provide baseline and final day urine samples. The exceptions to this were persons who would be on site less than 3 days such as casual visitors and delivery people. TLD's were sent to the Eberline Instrument Corporation (EIC) facility in Santa Fe, New Mexico for readout. No radiation exposure was detected above normal background on the TLD's. The urine samples were analyzed on site. None exceeded the lower limit of detectablility (LLD).

\section{RADIATION MONITORING EQUIPMENT}

On-site radioactivity measuring equipment during site cleanup consisted of:

a. A Packard Model 2003 liquid scintillation spectrometer was used for tritium analysis. Channel 1 was gated for maximum sensitivity in the tritium beta energy region while channels 2 and 3 were both gated for the full range of beta energies. For this system the LLD was approximately $2 \mathrm{pCi} / \mathrm{ml}$ for tritium at $3 \sigma$ above background.

b. Portable survey equipment included sensitive gamma detectors (EIC PRM-5 with SPA-2 $1 \times 1$ Na1 probe), general beta gamma detectors (EIC E-520 with HP-177 GM probe), thin window beta detectors $<7 \mathrm{mg} / \mathrm{cm}^{2}$ (EIC MS-2 and PRM 5-3 with HP-210 probes) and gas proportional alpha detector (EIC PAC-4G with $50 \mathrm{~cm}^{2}$ AC-21 probe). The thin window beta probe (HP-210) has a sensitivity of 1800 $\mathrm{cpm} / \mathrm{mrad} / \mathrm{hr}$.

\section{PLUGGING AND ABANDOMENT ACTIVITIES}

Wells GB-1, GB-2, GB-3 and GB-D were plugged and abandoned without incident. 
Since these wells have no history of radioactive contaminations, the operations during abandonment received only minimal radiological support. Swipe samples were taken of equipment used at this time and samples of drilling mud and water used were checked for tritium contamination. Tools and wellhead components were routinely steam cleaned for cosmetic reasons, even though no contamination was encountered.

One sample of mud from the GB-3 abandonment operations indicated $6 \mathrm{pCi} / \mathrm{mi}$ of tritium. The activity was suspected to be the result of natural thorium daughters from drilling mud chemicals, and a second analysis by distillation showed <LLD for tritium. The mud contained a large amount of paraffin (a four inch layer in the mud tank). The entire mix of water, mud and paraffin was buried on site. See Figure 11 for location of this burial, labeled $\mathrm{C}$.

The abandonment of GB-1, GB-2, GB-3 and GB-D wells was completed and the rig was moved to GB-ER.

Prior to the removal of the wellhead, a moisture sample was collected by passing gas from the GB-ER production tubing through a molecular sieve for several hours. This sample read $11,508 \mathrm{pCi} / \mathrm{ml}$ of tritium in gas borne moisture. Gas samples were not taken and evaluated for tritium content of the gas itself due to insufficient pressure for the small gas sample bottles available.

From the time work began on GB-ER, all personnel involved wore necessary protective clothing and continual radiological surveillance was established.

No personnel contamination occurred during the abandonment work on GB-ER and only minimal contamination of equipment and tools was encountered.

The McCullough wire line used for inserting the GB-ER casing plus was bundled for shipment as low level waste because decontamination was impractical due to the braided construction of the cable.

All pipe and tubing used during the abandonment of GB-ER were steam decontaminated and sent to DOE for use at NTS. The rig and tools were steam decontaminated and returned to their owners. All trucks were monitored and the wire line truck and rig were steam decontaminated. All swipes of steam cleaned equipment, trucks and tools were found to be below the release criteria.

\section{DECONTAMINATION ACTIVITIES}

The only decontamination method employed was steam cleaning. A decontamination pan was installed on a graded $3^{\circ}$ slope adjacent to the steam generator and a controlled area was established around the pan using yellow rope and appropriate radiation warning signs. All decontamination work occurred within this controlled area. (See Figure 4)

A second controlled area was established to receive the released items. Within this area items were segregated as to ownership, i.e., DOE or EPNG. A third segment of this area was established for the storage of contaminated material barrels slated for shipment to NTS for burial as low level radioactive waste.

A log of all material released and stored in this area was maintained. A total of 425 items ranging from boxes of nuts and bolts to gas/liquid separators were checked (see Section V Procedures Supplement for the Radiological Field Operations Plan, NVO 195, for analytical methods employed) and found to be below the release criteria and were released for unrestricted use. Although all items subjected to the initial steam decontamination were below the release criteria, a few selected items were steam 
decontaminated a second time and indeed showed somewhat lower levels of activity. It was felt that the added time and effort to do this for all items was not worth the cost at these initial low levels of activity.

\section{SITE SAMPLING AND SURVEY ACTIVITIES}

To delineate the extent of radioactive contamination of the Gasbuggy site numerous environmental samples were collected and analyzed.

No radionuclides other than tritium or those naturally occurring were encountered during the Gasbuggy cleanup operation.

The tritium levels encountered were found to be well below all applicable release criteria as specified in NVO-195 (see Table 8). The highest level of tritium found was in a soil sample which contained a tritium concentration of $1,303 \mathrm{pCi} / \mathrm{ml}$ of soil moisture. This represents less than $5 \%$ of the release criteria (see Table 8).

a. Surface Soil Samples

In the first 3 weeks of October 1973 EPNG carried out a soil sampling survey of the Gasbuggy site. They sampled at a dpth of 24 inches on a 50 foot grid over the entire fenced area. This grid used the GB-ER as the 0 point with true North-South as the vertical and true East-West the horizontal. Their findings were made available and appreciation is hereby acknowledged as it greatly assisted the final cleanup effort.

Site soil sampling points were set up similarly on a 50 foot grid with a sampling depth of 12 inches and was offset from EPNG sampling locations by shifting the 0 point 25 feet North and 25 feet East or 35.36 feet NE of GB-ER Vertical is true North-South and horizontal true East-West. The sampling grid was accurately surveyed using the GB-ER as a permanent reference.

One-hundred sixty-five (165) soil samples were taken and only 9 exceeded the lower limit of detectability (LLD). The LLD for tritium in soil was $2 \mathrm{pCi} / \mathrm{ml}$ at $3 \sigma$ above background. See Table 1 for results and Figure 4 for locations.

b. Profile Soil Samples

The surface soil sample results guided selections of sampling points for the profile sets. The highest readings were selected first, 12 locations on site and 9 locations off site for an initial total of 21 locations (see Figure 5 for sample locations). The results from these determined the selections of 8 more locations and the need to go deeper than the original 6 feet at a few of the first 21 locations. From the results of these last 8 it was determined that 5 more locations would need to be sampled to completely define the extent and quantity of subsurface contamination. During the cleanup, advantage was taken of 3 operational holes which were dug to obtain three random profile sets.

Of the total of 32 profile sets 15 had readings of $>10 \mathrm{pCi} / \mathrm{ml}$ at all depths. Two had only one reading $>10 \mathrm{pCi} / \mathrm{ml}$ but $<50 \mathrm{pCi} / \mathrm{ml}$ while 15 had positive readings ranging from 10 to $1303 \mathrm{pCi} / \mathrm{ml}$ at all levels. See Figure 5 for locations, Table 2 and Figures 6, 7, 8 and 9 for results.

Profile \#1 located at Grid W1, 0 near where the separators were located, and \#22 at $\mathrm{E} 1 \mathrm{~N} 1+\mathrm{N} 10^{\prime}$ and $\mathrm{W} 18^{\prime}$ and $\# 23$ at $\mathrm{E} 1 \mathrm{~N} 1+\mathrm{N} 16^{\prime}$ and $33^{\prime}$ ' where the pump shack and red tank were located, were the only two locations of potential contamination not directly associated with the flare stack and steamer shack. The other 12 positive profiles were all in the flare stack and steam shed area and were 
used to define the extent of the the soil contamination there. Profiles \#11, 15, 16, 17, $25,26 \& 27$ were located North of the flare stack, and Profiles \#13, 14, 18 \& 24, West and South of the flare stack. Profile \#24 at E3, N2 + 45' N 17' W contained the highest concentrations found on site at a depth of 4 feet and was felt to be the center of the major contributions to the subsurface contamination in this area. The total size of this area is about $5000 \mathrm{ft}^{2}$. The depth varied in part because of an old solid mud barrier at 5 feet in a portion of this area. Penetration of this barrier in two locations yielded soil samples that contained no detectable tritium. An average depth for this $5000 \mathrm{ft}^{2}$ area was then felt to be about 5 feet. Using weighted averages and conservative assumptions the total activity in this mass is estimated to be less than $8 \mathrm{mCi}$ tritium.

The two areas represented in Profile \#1 and \#'s 22 and 23 were much smaller being about $50 \mathrm{ft}^{2}$ and $150 \mathrm{ft}^{2}$, respectively, and contribute only a maximum of 0.36 $\mathrm{mCi}$ to the total tritium activity left in the Gasbuggy soil.

The highest level of activity found during the 1973 EPNG survey of the Gasbuggy site was $11,200 \mathrm{pCi} / \mathrm{ml}$ of soil moisture at a depth of 4 feet from a profile set near the Flare Stack. This sample was taken October 10, 1973.

The highest level soil sample was taken very close to this spot on September 19 , 1978 , also from profile set (\#24) and at a depth of 4 feet. It read 1,303 pCi/ml of soil moisture.

\section{c. Operational Soil Samples}

A number of soil samples were taken in support of the cleanup whenever a hole needed to be dug or the soil disturbed. These samples indicated that no hazard to personnel from tritium existed during these operations.

A final surface soil survey was conducted to determine that the cleanup operation itself made no contribution to the surface contamination of the site. Forty-five (45) samples were taken in locations selected because there were cleanup related activities in these areas.

The sampling method employed was to remove man made and vegetative material from the surface and then take $100 \mathrm{~cm}^{2}$ of soil to a sufficient depth to assure enough moisture for a soil moisture by distillation analysis. Twenty-seven (27) of the samples were <LLD, 15 were between 2 and $10 \mathrm{pCi} / \mathrm{ml}$ and only 3 were $>10 \mathrm{pCi} / \mathrm{ml}$. All three of these fell in areas of known previous contamination.

a. Under the Steamer Shack $60.7 \mathrm{pCi} / \mathrm{ml}$;

b. Around the Steamer Shack $63.1 \mathrm{pCi} / \mathrm{ml}$;

c. Six feet East of GB-ER $17.3 \mathrm{pCi} / \mathrm{ml}$;

d. Operational Water Samples

Water samples were collected in support of the cleanup operation. The source of site water was a spring located about 5 miles from the site.

Samples of this water indicated <LLD of tritium. Water used to circulate mud and gel in GB-ER was periodically sampled and typically falsely indicated about $6 \mathrm{pCi} / \mathrm{ml}$ tritium after mixing with mud most probably due to natural isotopes in the mud itself. This was verified when samples were distilled.

Sludge samples were treated as water samples. Samples from the red tank sludge, separators, flare line, water line and numerous pour through samples were processed. Samples were taken both before and after decontamination 
efforts. The highest tritium water sample reading was $38,000 \mathrm{pCi} / \mathrm{ml}$ associated with sludge from the bottom of the red tank which became a part of barrel \#1 to be shipped to NTS for burial.

\section{e. Beta Gamma Survey}

The site was beta-gamma surveyed after all the site activity was complete with the exception of the reseeding. A portable thin window $<7 \mathrm{mg} / \mathrm{cm}^{2}$ pancake geiger counter PRM-5-3 (EIC HP-210 probe), SN 1987, calibrated $8 / 10 / 78$ was used. A 30 second count was made at each of the soil sampling locations, as shown in Figure 4, by holding the counter just a few centimeters above the ground. All readings were $<.05 \mathrm{mrad} / \mathrm{hr}$ for beta/gamma. Average probe background was approximately $.036 \mathrm{mrad} / \mathrm{hr}$. away from site.

f. Additional Analysis

Additional analysis was provided by off-site EIC laboratories. Strontium-90 quantification on 8 samples and one sample for plutonium were performed by the EIC Albuquerque facility. Other isotopic identification was made on 8 samples by GeLi detector at the midwest facility. Results are in Tables 4 and 5.

\section{g. Vegetation Samples}

Six (6) vegetation samples were collected and submitted to the U.S.

Environmental Protection Agency, Las Vegas, Nevada 89114 for analysis. Results appear in Table 6 . The results were consistent with soil samples taken in the various areas. The vegetation samples represented quite a large area compared with soil samples due to the sparsity of available vegetation to obtain a required sample weight.

h. Quality Control

Quality control was maintained by using NBS standards and following standard laboratory practices of using blanks and duplicate samples.

\section{DISPOSITION OF OTHER SITE MATERIALS}

The site contained an unused concrete decontamination pad at the end of which was a plastic lined sump. This pad and several concrete trailer parking pads were broken up and buried in the enlarged unused decontamination sump. The sump was back filled and the area brought to natural grade. Swipe samples of the concrete pieces read $\angle L L D$ in $\beta$ activity and $\angle L L D$ in tritium activity. Soil samples taken in the sump also read <LLD for tritium. These samples confirm that it was an unused decontamination pad and sump. No radioactive material was disposed of in this burial. See Figure 11 Area B for this location.

Mud and gel loaded water used during the various milling and plugging operations was buried at 3 separate locations. Samples of this material falsely read about $6 \mathrm{pCi} / \mathrm{ml}$ tritium. Samples after distillation were $\angle L L D$ indicating the $6 \mathrm{pCi} / \mathrm{ml}$ was due to naturally occurring thorium daughters associated with drilling mud. See Figure 11 areas $A, C$ \& $D$ for locations of these burials.

The past history of the samples taken from the Gasbuggy ground zero site, the numerous samples analyzed for beta and gamma emitters during this operation, the beta-gamma survey of the site itself and samples sent to other laboratories for detailed analyses confirms that tritium is the only radioactive isotope, other than naturally occurring radioactive istopes and worldwide fallout to be found in the Gasbuggy soil at this time. 


\section{CONCLUSIONS}

No beta-gamma radionuclides other than tritium or naturally occurring radioisotopes were found during the Gasbuggy cleanup. No plutonium was found in "Red Tank" residue.

Only low levels of tritium were detected in soils and none in air or urine.

No exposure above natural background amounts resulted to personnel during the cleanup operations.

All equipment contaminated during gas production testing in the past and equipment used during the cleanup operations was decontaminated to well below release criteria and was released for unrestricted use.

It should be noted that the average concentrations of tritium remaining after this cleanup operation are small fractions of the RCG levels of 10 CFR 20 and DOE manual chapters. This cleanup therefore reflects the best effort of all parties to reduce contaminants to the lowest practicable level. 


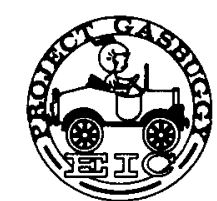

TABLE 1

Surface Soil Samples (12" to 14")

$\begin{array}{llll}\text { No. } & \begin{array}{c}\text { Grid } \\ \text { Location }\end{array} & \text { Depth } & \begin{array}{c}\text { Soil Moisture } \\ { }^{3 \mathbf{H ~ p C i} / \mathbf{m l}}\end{array} \\ 1 & \text { W3 N9 } & 1 \mathrm{ft} . & 5.2 \\ 2 & \text { W1 } & 1 \mathrm{ft} . & 965 \\ 3 & \text { W1 }+25, & 1 \mathrm{ft} . & 5.3 \\ 4 & 0 \mathrm{~N} 2 & 1 \mathrm{ft} . & 20 \\ 5 & \text { E1 N3 } & 1 \mathrm{ft} . & 16 \\ 6 & \text { E1 N4 } & 1 \mathrm{ft} . & 23.5 \\ 7 & \text { E2 S3 } & 1 \mathrm{ft} . & 8 \\ 8 & \text { E2 N3 } & 1 \mathrm{ft} . & 20.4 \\ 9 & \text { E3 N3 } & 1 \mathrm{ft} . & 8.6\end{array}$

All other, 12" to 14 " soil samples were < LLD $(2 \mathrm{pCi} / \mathrm{ml} @ 3 \sigma$ counting error for Tritium)

165 total, 12 " to 14 " soil samples were taken. 


\section{TABLE 2}

\section{Profile Soil Sample Sets}

\begin{tabular}{|c|c|c|c|c|}
\hline Hole No. & $\begin{array}{c}\text { Grid } \\
\text { Location }\end{array}$ & \multicolumn{3}{|c|}{$\begin{array}{l}\text { Soll Molsture } \\
{ }^{3} \mathrm{H} \mathrm{pCl} / \mathrm{ml}\end{array}$} \\
\hline 1 & W1 No & $1 \mathrm{ft}$. & & 154 \\
\hline$"$ & $"$ & $2 \mathrm{ft}$. & & 180 \\
\hline$"$ & $"$ & $3 \mathrm{ft}$. & & 234 \\
\hline$"$ & $"$ & $4 \mathrm{ft}$. & & 232 \\
\hline$"$ & $"$ & $5 \mathrm{ft}$. & & 249 \\
\hline$"$ & " & $6 \mathrm{ft}$. & & 558 \\
\hline 2 & W6 S3 & $1 \mathrm{ft}$ & & LLD \\
\hline$"$ & $"$ & $2 \mathrm{ft}$. & & LLD \\
\hline$"$ & " & $3 \mathrm{ft}$. & & LLD \\
\hline ," & $"$ & $4 \mathrm{ft}$. & & LLD \\
\hline$"$ & $"$ & $5 \mathrm{ft}$. & & LLD \\
\hline$"$ & $"$ & $6 \mathrm{ft}$ & & LLD \\
\hline 3 & W3 N4 & $1 \mathrm{ft}$. & & LLD \\
\hline$"$ & $"$ & $2 \mathrm{ft}$ & & LLD \\
\hline$"$ & $"$ & $3 \mathrm{ft}$. & & LLD \\
\hline$"$ & $"$ & $4 \mathrm{ft}$. & & LLD \\
\hline$"$ & $"$ & $5 \mathrm{ft}$. & & LLD \\
\hline$"$ & $"$ & $6 \mathrm{ft}$. & & LLD \\
\hline 4 & W2 N9 & $1 \mathrm{ft}$. & & LLD \\
\hline$"$ & ", & $2 \mathrm{ft}$. & & LLD \\
\hline$"$ & $"$ & $3 \mathrm{ft}$. & & LLD \\
\hline$"$ & $"$ & $4 \mathrm{ft}$. & & LLD \\
\hline$"$ & $"$ & $5 \mathrm{ft}$. & & LLD \\
\hline$"$ & $"$ & $6 \mathrm{ft}$ & & LLD \\
\hline 5 & E4 N9 & $1 \mathrm{ft}$. & & LLD \\
\hline$"$ & $"$ & $2 \mathrm{ft}$. & ${ }^{\star}(\mathrm{RC}<\mathrm{LLD})$ & 2.3 \\
\hline$"$ & $"$ & $3 \mathrm{ft}$. & (RC < LLD) & 1.9 \\
\hline$"$ & ", & $4 \mathrm{ft}$. & & LLD \\
\hline$"$ & $"$ & $5 \mathrm{ft}$. & & LLD \\
\hline ", & $"$ & $6 \mathrm{ft}$. & & LLD \\
\hline
\end{tabular}

*RC means Recount (LLD 2pCi/ml @ $3 \sigma$ counting error for Tritium). 
TABLE 2 (Continued)

Profile Soil Sample Sets

\begin{tabular}{|c|c|c|c|}
\hline Hole No. & $\begin{array}{c}\text { Grid } \\
\text { Location }\end{array}$ & Depth & $\begin{array}{l}\text { Soil Moisture } \\
{ }^{3} \mathrm{H} \mathrm{pCi} / \mathrm{ml}\end{array}$ \\
\hline 6 & E1 N9 & $1 \mathrm{ft}$ & $<$ LLD \\
\hline$"$ & $"$ & $2 \mathrm{ft}$. & $<$ LLD \\
\hline$"$ & $"$ & $3 \mathrm{ft}$. & $<$ LLD \\
\hline$"$ & $"$ & $4 \mathrm{ft}$. & $<$ LLD \\
\hline$"$ & $"$ & $5 \mathrm{ft}$. & $<$ LLD \\
\hline$"$ & $"$ & $6 \mathrm{ft}$. & $<$ LLD \\
\hline 7 & E3 N7 & $1 \mathrm{ft}$. & $<$ LLD \\
\hline$"$ & $"$ & $2 \mathrm{ft}$. & $<$ LLD \\
\hline$"$ & $"$ & $3 \mathrm{ft}$. & $<$ LLD \\
\hline$"$ & $"$ & $4 \mathrm{ft}$. & $<$ LLD \\
\hline$"$ & $"$ & $5 \mathrm{ft}$. & $<$ LLD \\
\hline$"$ & $"$ & $6 \mathrm{ft}$. & $<$ LLD \\
\hline 8 & E6 N4 & $1 \mathrm{ft}$. & $<$ LLD \\
\hline$"$ & $"$ & $2 \mathrm{ft}$. & $<$ LLD \\
\hline$"$ & $"$ & $3 \mathrm{ft}$. & $<$ LLD \\
\hline$"$ & $"$ & $4 \mathrm{ft}$. & $<$ LLD \\
\hline$"$ & $"$ & $5 \mathrm{ft}$. & $<$ LLD \\
\hline$"$ & $"$ & $6 \mathrm{ft}$. & < LLD \\
\hline 9 & $\begin{array}{l}223 \text { yds } S \text { of GB-ER } \\
\text { on Grid E2 }\end{array}$ & $1 \mathrm{ft}$. & $<$ LLD \\
\hline$"$ & $"$ & $2 \mathrm{ft}$. & $<$ LLD \\
\hline$"$ & $"$ & $3 \mathrm{ft}$. & $<$ LLD \\
\hline$"$ & $"$ & $4 \mathrm{ft}$. & $<$ LLD \\
\hline$"$ & $"$ & $5 \mathrm{ft}$. & $<$ LLD \\
\hline$"$ & $"$ & $6 \mathrm{ft}$. & $<$ LLD \\
\hline 10 & E3 N5 & $1 \mathrm{ft}$. & $<$ LLD \\
\hline$"$ & $"$ & $2 \mathrm{ft}$. & $<$ LLD \\
\hline$"$ & $"$ & $3 \mathrm{ft}$. & $<$ LLD \\
\hline$"$ & $"$ & $4 \mathrm{ft}$. & $<$ LLD \\
\hline$"$ & $"$ & $5 \mathrm{ft}$. & $<$ LLD \\
\hline$"$ & $"$ & $6 \mathrm{ft}$ & $<$ LLD \\
\hline
\end{tabular}




\section{TABLE 2 (Continued) Profile Soll Sample Sets}

Hole No.

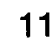

\section{Grid}

Location

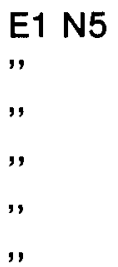

E4 N2

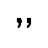

,

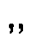

,

,

,

E2 N3

,

,

,

,

",

,

,
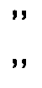

E3 N3

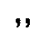

,

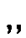

,

",

"

E2 N4
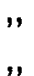

"

"

"

"

\section{Depth}

$1 \mathrm{ft}$.

$2 \mathrm{ft}$.

$3 \mathrm{ft}$.

$4 \mathrm{ft}$.

$5 \mathrm{ft}$.

$6 \mathrm{ft}$.

$1 \mathrm{ft}$.

$2 \mathrm{ft}$.

$3 \mathrm{ft}$.

$4 \mathrm{ft}$.

$5 \mathrm{ft}$.

$6 \mathrm{ft}$.

$1 \mathrm{ft}$.

$2 \mathrm{ft}$.

$3 \mathrm{ft}$.

$4 \mathrm{ft}$.

$5 \mathrm{ft}$.

$6 \mathrm{ft}$.

$6 \mathrm{ft}$.

$7 \mathrm{ft}$.

$8 \mathrm{ft}$.

$1 \mathrm{ft}$.

$2 \mathrm{ft}$.

$3 \mathrm{ft}$.

$4 \mathrm{ft}$.

$5 \mathrm{ft}$.

$6 \mathrm{ft}$.

$1 \mathrm{ft}$.

$2 \mathrm{ft}$.

$3 \mathrm{ft}$.

$4 \mathrm{ft}$.

$5 \mathrm{ft}$.

$6 \mathrm{ft}$.

\section{Soll Moisture}

${ }^{3} \mathrm{H}$ pCl/ml

13.3

$<$ LLD

2.0

$<$ LLD

1.8

1.6

$<$ LLD

$<$ LLD

$<$ LLD

$<$ LLD

2.6

13.4

52.0

31.7

331

131

919

980

6.8

$<$ LLD

$<$ LLD

39.9

135

311

422

282

83

3.2

10.2

23.1

39.1

34.3

18.8 
TABLE 2 (Continued)

\section{Profile Soil Sample Sets}

\begin{tabular}{|c|c|c|c|}
\hline Hole No. & $\begin{array}{c}\text { Grid } \\
\text { Location }\end{array}$ & Depth & $\begin{array}{l}\text { Soil Molsture } \\
{ }^{3} \mathrm{H} \mathrm{pCl} / \mathrm{ml}\end{array}$ \\
\hline 16 & E3 N4 & $1 \mathrm{ft}$. & 9.8 \\
\hline$"$ & $"$ & $2 \mathrm{ft}$. & 8.6 \\
\hline$"$ & $"$ & $3 \mathrm{ft}$. & 12.2 \\
\hline$"$ & $"$ & $4 \mathrm{ft}$. & 10.1 \\
\hline$"$ & $"$ & $5 \mathrm{ft}$. & 16.2 \\
\hline$"$ & $"$ & $6 \mathrm{ft}$. & 18.8 \\
\hline$"$ & $"$ & $9 \mathrm{ft}$. & 71.5 \\
\hline ", & $"$ & $10 \mathrm{ft}$. & 72.2 \\
\hline$"$ & $"$ & $11 \mathrm{ft}$. & 71.2 \\
\hline$"$ & $"$ & $12 \mathrm{ft}$. & 73.3 \\
\hline 17 & E1 N4 & $1 \mathrm{ft}$. & 22.3 \\
\hline$"$ & $"$ & $2 \mathrm{ft}$ & 74.3 \\
\hline$"$ & $"$ & $3 \mathrm{ft}$. & 117.2 \\
\hline$"$ & $"$ & $4 \mathrm{ft}$. & 79.4 \\
\hline$"$ & $"$ & $5 \mathrm{ft}$ & 24.0 \\
\hline$"$ & $"$ & $6 \mathrm{ft}$. & 6.1 \\
\hline 18 & E1 N3 & $1 \mathrm{ft}$ & 6.7 \\
\hline$"$ & $"$ & $2 \mathrm{ft}$. & 20.4 \\
\hline$"$ & $"$ & $3 \mathrm{ft}$. & 23.5 \\
\hline$"$ & $"$ & $4 \mathrm{ft}$. & 30.7 \\
\hline$"$ & $"$ & $5 \mathrm{ft}$. & 24.1 \\
\hline$"$ & $"$ & $6 \mathrm{ft}$. & 14.3 \\
\hline 19 & 0 N2 & $1 \mathrm{ft}$. & 4.7 \\
\hline$"$ & $"$ & $2 \mathrm{ft}$. & 7.1 \\
\hline$"$ & $"$ & $3 \mathrm{ft}$. & 6.6 \\
\hline$"$ & $"$ & $4 \mathrm{ft}$. & 5.2 \\
\hline$"$ & $"$ & $5 \mathrm{ft}$. & 3.0 \\
\hline$"$ & $"$ & $6 \mathrm{ft}$. & $<$ LLD \\
\hline 20 & E6 S1 & $1 \mathrm{ft}$. & $<$ LLD \\
\hline$"$ & $"$ & $2 \mathrm{ft}$. & $<$ LLD \\
\hline$"$ & $"$ & $3 \mathrm{ft}$ & $<$ LLD \\
\hline$"$ & $"$ & $4 \mathrm{ft}$. & $<$ LLD \\
\hline$"$ & $"$ & $5 \mathrm{ft}$. & $<$ LLD \\
\hline$"$ & $"$ & $6 \mathrm{ft}$. & $<$ LLD \\
\hline
\end{tabular}

(LLD 2pCi/ml @ $3 \sigma$ counting error for Tritium) 
TABLE 2 (Continued)

Profile Soil Sample Sets

Grid
Hole No.

21

"

,

,

"

"

22

,

,

"

"

"

$"$

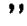

23

,

,

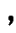

,

"

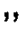

,

$24 \quad$ E3 N2 + 45' N 17' W

,
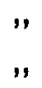

,

,

1,

",

"
W1 N1

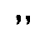

,

,

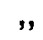

$"$

$\mathrm{E} 1 \mathrm{~N} 1+10^{\prime} \mathrm{N} 18^{\prime} \mathrm{W}$

$"$

$"$

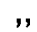

"'

,

$"$

$"$

$\mathrm{E} 1 \mathrm{~N} 1+16^{\prime} \mathrm{N} 33^{\prime} \mathrm{W}$

"

$"$

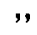

,

$"$

"

"

E3 $\mathrm{N} 2+45^{\prime} \mathrm{N} 17^{\prime} \mathrm{W}$

"

"

$"$

$"$

"

"
Depth

$1 \mathrm{ft}$.

$2 \mathrm{ft}$.

$3 \mathrm{ft}$.

$4 \mathrm{ft}$.

$5 \mathrm{ft}$.

$6 \mathrm{ft}$.

$1 \mathrm{ft}$.

$2 \mathrm{ft}$.

$3 \mathrm{ft}$.

$4 \mathrm{ft}$.

$5 \mathrm{ft}$.

$6 \mathrm{ft}$.

$7 \mathrm{ft}$.

$8 \mathrm{ft}$.

$1 \mathrm{ft}$.

$2 \mathrm{ft}$.

$3 \mathrm{ft}$.

$4 \mathrm{ft}$.

$5 \mathrm{ft}$.

$6 \mathrm{ft}$.

$7 \mathrm{ft}$.

$8 \mathrm{ft}$.

$1 \mathrm{ft}$.

$2 \mathrm{ft}$.

$3 \mathrm{ft}$.

$4 \mathrm{ft}$.

$5 \mathrm{ft}$.

$6 \mathrm{ft}$.

$7 \mathrm{ft}$.

$8 \mathrm{ft}$.
Soil Moisture

${ }^{3} \mathrm{H} \mathrm{pCl} / \mathrm{ml}$

$<$ LLD
$<$ LLD
$<$ LLD
$<$ LLD
$<$ LLD
$<$ LLD

9.3

7.4

6.9

7.3

23.7

99

298

218

2.7

6.8

10.2

10.8

34.9

49.9

69.2

59.6

49.3

135

434

1303

578

385

186

86.9 
TABLE 2 (Continued)

Profile Soil Sample Sets

\begin{tabular}{|c|c|c|c|}
\hline Hole No. & $\begin{array}{c}\text { Grid } \\
\text { Location }\end{array}$ & Depth & $\begin{array}{l}\text { Soil Moist } \\
{ }^{3} \mathrm{H} \text { pCiln }\end{array}$ \\
\hline 25 & $E 3 N 3+27^{\prime} N 14^{\prime} W$ & $1 \mathrm{ft}$. & 16.2 \\
\hline$"$ & $"$ & $2 \mathrm{ft}$. & 6.6 \\
\hline$"$ & $"$ & $3 \mathrm{ft}$. & 25.3 \\
\hline$"$ & $"$ & $4 \mathrm{ft}$. & 61.5 \\
\hline$"$ & $"$ & $5 \mathrm{ft}$. & 158 \\
\hline 26 & $\mathrm{E} 2 \mathrm{~N} 3+19^{\prime} \mathrm{N} 77^{\prime} \mathrm{W}$ & $1 \mathrm{ft}$ & 3.2 \\
\hline$"$ & $"$ & $2 \mathrm{ft}$. & 3.4 \\
\hline$"$ & $"$ & $3 \mathrm{ft}$. & 6.4 \\
\hline$"$ & $"$ & $4 \mathrm{ft}$. & 15.5 \\
\hline$"$ & $"$ & $5 \mathrm{ft}$. & 35.1 \\
\hline 27 & $E 2 N 3+32^{\prime} N 9^{\prime} E$ & $1 \mathrm{ft}$. & 4.9 \\
\hline$"$ & $"$ & $2 \mathrm{ft}$. & 13.0 \\
\hline$"$ & $"$ & $3 \mathrm{ft}$. & 10.6 \\
\hline$"$ & $"$ & $4 \mathrm{ft}$. & 31.5 \\
\hline$"$ & $"$ & $5 \mathrm{ft}$. & 52.5 \\
\hline 28 & E3 N2 + 21'N $11^{\prime} W$ & $\begin{array}{l}1 \mathrm{ft} . \\
2 \mathrm{ft}\end{array}$ & $\begin{array}{l}<\text { LLD } \\
<\text { LLD }\end{array}$ \\
\hline$"$ & $"$ & $3 \mathrm{ft}$. & $<$ LLD \\
\hline$"$ & $"$ & $4 \mathrm{ft}$. & $<$ LLD \\
\hline$"$ & $"$ & $5 \mathrm{ft}$. & $<$ LLD \\
\hline$"$ & $"$ & $6 \mathrm{ft}$. & 2.5 \\
\hline$"$ & $"$ & $7 \mathrm{ft}$. & $<$ LLD \\
\hline$"$ & $"$ & $8 \mathrm{ft}$. & $<$ LLD \\
\hline 29 & $\mathrm{E} 2 \mathrm{~N} 2+21^{\prime} \mathrm{E}$ & $1 \mathrm{ft}$. & $<$ LLD \\
\hline$"$ & $"$ & $2 \mathrm{ft}$. & 2.2 \\
\hline$"$ & $"$ & $3 \mathrm{ft}$. & < LLD \\
\hline$"$ & $"$ & $4 \mathrm{ft}$. & $<$ LLD \\
\hline$"$ & $"$ & $5 \mathrm{ft}$. & $<$ LLD \\
\hline$"$ & $"$ & $6 \mathrm{ft}$. & 31.5 \\
\hline$"$ & $"$ & $7 \mathrm{ft}$. & $<$ LLD \\
\hline$"$ & $"$ & $8 \mathrm{ft}$. & $<$ LLD \\
\hline
\end{tabular}


TABLE 2 (Continued)

Profile Soil Sample Sets

\begin{tabular}{|c|c|c|c|}
\hline Hole No. & $\begin{array}{c}\text { Grid } \\
\text { Location }\end{array}$ & Depth & $\begin{array}{l}\text { Soll Moistur } \\
{ }^{3} \mathrm{H} \text { pCi/ml }\end{array}$ \\
\hline 30 & $\begin{array}{l}\text { E2 N2 } \\
"\end{array}$ & $1 \mathrm{ft}$. & $<$ LLD \\
\hline$"$ & $"$ & $2 \mathrm{ft}$. & $<$ LLD \\
\hline$"$ & 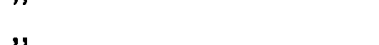 & $3 \mathrm{ft}$. & < LLD \\
\hline$"$ & $"$ & $4 \mathrm{ft}$. & 3.2 \\
\hline$"$ & $"$ & $5 \mathrm{ft}$. & $<$ LLD \\
\hline$"$ & $"$ & $6 \mathrm{ft}$. & $<$ LLD \\
\hline$"$ & $"$ & $7 \mathrm{ft}$. & $<$ LLD \\
\hline$"$ & $"$ & $8 \mathrm{ft}$. & 4.9 \\
\hline 33 & E4 N3 + 38' N 19، W & $\begin{array}{l}1 \mathrm{ft} . \\
2 \mathrm{ft} .\end{array}$ & $\begin{array}{l}<\text { LLD } \\
<\text { LLD }\end{array}$ \\
\hline$"$ & $"$ & $3 \mathrm{ft}$. & $<$ LLD \\
\hline$"$ & $"$ & $4 \mathrm{ft}$. & $<$ LLD \\
\hline$"$ & $"$ & $5 \mathrm{ft}$. & 3.7 \\
\hline$"$ & $"$ & $6 \mathrm{ft}$. & 6.9 \\
\hline$"$ & $"$ & $7 \mathrm{ft}$. & 5.1 \\
\hline$"$ & $"$ & $8 \mathrm{ft}$. & 3.2 \\
\hline Rerun 1 & W1 NO & $1 \mathrm{ft}$. & 74.5 \\
\hline$"$ & $"$ & $2 \mathrm{ft}$. & 69.3 \\
\hline$"$ & $"$ & $3 \mathrm{ft}$. & 60.7 \\
\hline$"$ & $"$ & $4 \mathrm{ft}$. & 126 \\
\hline$"$ & $"$ & $5 \mathrm{ft}$. & 164 \\
\hline$"$ & $"$ & $6 \mathrm{ft}$. & 121 \\
\hline$"$ & $"$ & $7 \mathrm{ft}$. & 112 \\
\hline$"$ & $"$ & $8 \mathrm{ft}$. & 63.9 \\
\hline$"$ & $"$ & $9 \mathrm{ft}$. & 40.4 \\
\hline$"$ & $"$ & $10 \mathrm{ft}$. & 24.7 \\
\hline Rerun 12 & E4 N2 & $1 \mathrm{ft}$. & 3.8 \\
\hline$"$ & $"$ & $2 \mathrm{ft}$. & 9.2 \\
\hline$"$ & $"$ & $3 \mathrm{ft}$. & 4.2 \\
\hline$"$ & $"$ & $4 \mathrm{ft}$. & 7.8 \\
\hline$"$ & $"$ & $5 \mathrm{ft}$. & 33.1 \\
\hline$"$ & $"$ & $6 \mathrm{ft}$. & 42.3 \\
\hline$"$ & $"$ & $7 \mathrm{ft}$. & 44.9 \\
\hline$"$ & $"$ & $8 \mathrm{ft}$. & 31.3 \\
\hline
\end{tabular}




\section{TABLE 2 (Continued)}

\section{Profile Soil Sample Sets}

\begin{tabular}{|c|c|c|c|}
\hline Hole No. & $\begin{array}{c}\text { Grid } \\
\text { Location }\end{array}$ & Depth & $\begin{array}{l}\text { Soil Mois } \\
{ }^{3} \mathrm{H} \mathrm{pCi} /\end{array}$ \\
\hline $\begin{array}{l}\text { Rerun } 13 \\
\text { " } \\
\text { " } \\
\text { " }\end{array}$ & $\begin{array}{l}\text { E2 N3 } \\
" \\
" \\
" \\
"\end{array}$ & $\begin{array}{l}1 \mathrm{ft} . \\
2 \mathrm{ft} . \\
3 \mathrm{ft} . \\
4 \mathrm{ft} . \\
5 \mathrm{ft} .\end{array}$ & $\begin{array}{r}15.7 \\
38.1 \\
83.2 \\
34.6 \\
181\end{array}$ \\
\hline $\begin{array}{l}\text { Rerun } 16 \\
\text { " } \\
" \\
" \\
" \\
" \\
" \\
"\end{array}$ & $\begin{array}{l}\text { E3 N4 } \\
\text { " } \\
" \\
" \\
" \\
" \\
" \\
"\end{array}$ & $\begin{array}{l}1 \mathrm{ft} . \\
2 \mathrm{ft} . \\
3 \mathrm{ft} . \\
4 \mathrm{ft} . \\
5 \mathrm{ft} . \\
6 \mathrm{ft} . \\
7 \mathrm{ft} . \\
8 \mathrm{ft} .\end{array}$ & $\begin{array}{r}9.7 \\
4.6 \\
8.3 \\
10.5 \\
12.0 \\
31.2 \\
53.4 \\
54.1\end{array}$ \\
\hline
\end{tabular}


TABLE 3

POST OPERATIONAL SURFACE SOIL SAMPLES

\begin{tabular}{|c|c|c|c|}
\hline $\begin{array}{l}\text { Sample } \\
\text { Number }\end{array}$ & $\begin{array}{l}\text { Collection } \\
\text { Date }\end{array}$ & $\begin{array}{c}\text { Site } \\
\text { Location }\end{array}$ & $\begin{array}{l}\text { Soil Moisture } \\
{ }^{3} \mathrm{H} \mathrm{pCl} / \mathrm{ml}\end{array}$ \\
\hline 1 & $9 / 23 / 78$ & $\begin{array}{l}\text { Near Red Tank and } \\
\text { Pump Shack }\end{array}$ & $<$ LLD \\
\hline 2 & $"$ & $"$ & 3.3 \\
\hline 3 & , & $"$ & $<$ LLD \\
\hline 4 & $"$ & $"$ & $<$ LLD \\
\hline 5 & $"$ & $"$ & $<$ LLD \\
\hline 6 & $"$ & $"$ & $<$ LLD \\
\hline 7 & $"$ & $\begin{array}{l}\text { Along waterline from } \\
\text { Red Tank }\end{array}$ & $<$ LLD \\
\hline 8 & $"$ & $"$ & $<$ LLD \\
\hline 9 & $"$ & Along gas lines & $<$ LLD \\
\hline 10 & $"$ & " & $<$ LLD \\
\hline 11 & $"$ & ", & $<$ LLD \\
\hline 12 & $"$ & 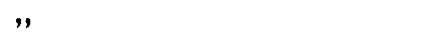 & $<$ LLD \\
\hline 23 & $"$ & Along old flare line & $<$ LLD \\
\hline 24 & $"$ & " & $<$ LLD \\
\hline 25 & $"$ & $"$ & $<$ LLD \\
\hline 26 & , & $"$ & $<$ LLD \\
\hline 27 & , & $"$ & $<$ LLD \\
\hline 28 & $"$ & $"$ & $<$ LLD \\
\hline 29 & $"$ & Around new operational & $<$ LLD \\
\hline 30 & $"$ & location of Red Tank & 3.0 \\
\hline 31 & $"$ & and Decon Pan & $<$ LLD \\
\hline 32 & $"$ & $"$ & $<$ LLD \\
\hline 33 & $"$ & $"$ & 1.7 \\
\hline 34 & $"$ & $"$ & 10.5 \\
\hline 35 & $"$ & $"$ & 4.0 \\
\hline 36 & $"$ & $"$ & 3.9 \\
\hline 37 & ", & ", & 2.6 \\
\hline 38 & $"$ & $"$ & 2.4 \\
\hline 39 & ", & ", & 1.8 \\
\hline
\end{tabular}

See Figure 10 for location

(LLD $2 \mathrm{pCi} / \mathrm{ml} @ 3 \sigma$ counting error for Tritium) 
TABLE 3 (Continued)

POST OPERATIONAL SURFACE SOIL SAMPLES

Sample
Number
40
41
42
43
44
13
14
15
16
17
18
19
20
21
22
46
45

\section{Collection \\ Date}

$9 / 23 / 78$

"

"

$9 / 25 / 78$

",

,

,

,

,

,

",

,

",

,

",

,

"

\section{Site \\ Location}

Around Steamer Shack

"

$"$

Around Steamer Shack

Under Steamer Sump

Where the separators sat

"

"

"

",

$"$

6'N from GBER

6'E from GBER

6'S from GBER

6'W from GBER

At GBER

2.5' Under Steamer Sump
Soil Moisture

${ }^{3} \mathrm{H} \mathrm{pCi} / \mathrm{ml}$

5.9

6.6

2.9

63.1

60.7

$<$ LLD

$<$ LLD

$<$ LLD

2.5

$<$ LLD

$<$ LLD

$<$ LLD

17.3

2.1

< LLD

7.8

280

(LLD 2pCi/ml @ $3 \sigma$ counting error for Tritium) 
TABLE 4

DETERMINATION Of STRONTIUM-90 and

Plutonium-238 \& 239 in SOIL SAMPLES

\begin{tabular}{|c|c|c|c|c|c|c|}
\hline \multirow{2}{*}{$\begin{array}{c}\text { Sample } \\
\text { Identification }\end{array}$} & \multirow{2}{*}{$\begin{array}{c}\text { Date } \\
\text { Collected }\end{array}$} & \multicolumn{2}{|c|}{ Total Weight (g) } & \multicolumn{3}{|c|}{$\mathrm{pCi} / \mathrm{g}$ (dry) } \\
\hline & & Wet & Dry & Pu-238 & Pu-239 & Sr-90 \\
\hline $\begin{array}{l}\text { Red Tank sludge } \\
\text { GB-428-23-1145 }\end{array}$ & $8 / 23 / 78$ & 307.5 & 278.5 & $0.00 \pm 0.02$ & $0.00 \pm 0.02$ & $<0.07$ \\
\hline Separator & & & & & & \\
\hline $\mathrm{H}^{2} \mathrm{O}+$ Sludge & $8 / 31 / 78$ & & .300 & N/A & N/A & $<14.3$ \\
\hline $\begin{array}{l}\text { Forestry Rd \#357 } \\
\text { Distance from } \\
\text { site - } 4.4 \text { miles } \\
\text { Distance from } \\
\text { Highway } 64-4.4 \\
\text { miles - } 1 \mathrm{ft} \text {. } \\
\text { depth soil at } \\
\text { windmill }\end{array}$ & & 1150.4 & 1086.0 & N/A & $N / A$ & $<0.06$ \\
\hline $\begin{array}{l}\text { Forestry Rd \#357 } \\
\text { Distance from } \\
\text { site - } 4.4 \text { miles } \\
\text { Distance from } \\
\text { Highway } 64-4.4 \\
\text { miles - } 2 \mathrm{ft} \text {. } \\
\text { depth soil at } \\
\text { windmill }\end{array}$ & & 1057.4 & 982.5 & N/A & N/A & $<0.05$ \\
\hline
\end{tabular}

Red Tank sludge GB-428-23-1145

Separator

$\mathrm{H}^{2} \mathrm{O}$ Sludge

Forestry Rd \#357

Distance from

miles - $1 \mathrm{ft}$.

depth soil at

windmill

Forestry Rd \#357

Distance from

miles - $2 \mathrm{ft}$.

windmill 
TABLE 4 (Continued)

DETERMINATION OF STRONTIUM-90 AND

Plutonium.238 \& 239 in Soil Samples

\begin{tabular}{|c|c|c|c|c|c|c|}
\hline \multirow{2}{*}{$\begin{array}{c}\text { Sample } \\
\text { Identification }\end{array}$} & \multirow{2}{*}{$\begin{array}{c}\text { Date } \\
\text { Collected }\end{array}$} & \multicolumn{2}{|c|}{ Total Weight (g) } & \multicolumn{3}{|c|}{$\mathrm{pCi} / \mathrm{g}$ (dry) } \\
\hline & & Wet & Dry & Pu-238 & Pu-239 & Sr.90 \\
\hline $\begin{array}{l}1 \mathrm{ft} \text {. depth grid } \\
\text { West } 1 \text { - North } 0 \\
\text { Hole \#1 }\end{array}$ & $9 / 11 / 78$ & 178.4 & 152.0 & $N / A$ & N/A & $<0.03$ \\
\hline $\begin{array}{l}4 \mathrm{ft} \text {. depth } \\
\text { Hole \#24 }\end{array}$ & $9 / 19 / 78$ & 209.1 & 191.0 & N/A & N/A & $<0.12$ \\
\hline $\begin{array}{l}5 \mathrm{ft} \text {. depth } \\
\text { Hole \#1 grid } \\
\text { West } \\
\text { 1-North } 0\end{array}$ & $9 / 19 / 78$ & 388.3 & 331.0 & $N / A$ & N/A & $<0.04$ \\
\hline $\begin{array}{l}\text { Sludge from Decon } \\
\text { Sump \& Red } \\
\text { Tank } \\
\text { to be pumped } \\
\text { down GB-ER }\end{array}$ & $8 / 30 / 78$ & $\begin{array}{l}\text { Liquid } \\
148 \mathrm{ml}\end{array}$ & I Vol. & N/A & N/A & $<12.3 \mathrm{pCi} / \mathrm{l}$ \\
\hline
\end{tabular}

N/A - Not Analyzed 


\section{TABLE 5}

\section{Gamma Emitting Isotopes in Site Samples}

\begin{tabular}{|c|c|c|c|}
\hline $\begin{array}{c}\text { Sample } \\
\text { Identification }\end{array}$ & Nuclide & $\mathrm{pCi} / 1 \pm 2 \sigma$ & $\mathrm{pCi} / \mathrm{g} \pm 2 \sigma$ \\
\hline \multirow[t]{8}{*}{ Separator, water \& sludge } & $\mathrm{Pb}-212$ & $200 \pm 30$ & \\
\hline & $\mathrm{Pb}-214$ & $300 \pm 40$ & \\
\hline & TI-208 & $<50$ & \\
\hline & $\mathrm{Bi}-214$ & $<50$ & \\
\hline & $\mathrm{Bi}-212$ & $<300$ & \\
\hline & AC-228 & $<100$ & \\
\hline & $K-40$ & $750 \pm 300$ & \\
\hline & Cs-137 & $<80$ & \\
\hline \multirow{8}{*}{$\begin{array}{l}\text { Sludge from decon sample } \\
\text { red tank to be pumped } \\
\text { down GB-ER }\end{array}$} & $\mathrm{Pb}-212$ & $400 \pm 50$ & \\
\hline & $\mathrm{Pb}-214$ & $300 \pm 50$ & \\
\hline & TI-208 & $200 \pm 20$ & \\
\hline & $\mathrm{Bi}-214$ & $300 \pm 50$ & \\
\hline & $\mathrm{Bi}-212$ & $<400$ & \\
\hline & $A c-228$ & $100 \pm 20$ & \\
\hline & $K-40$ & $2000 \pm 500$ & \\
\hline & Cs-137 & $<50$ & \\
\hline Red Tank Sludge & $\mathrm{Pb}-212$ & & $0.6 \pm 0.1$ \\
\hline GB-428-23-1145 & $\mathrm{Pb}-214$ & & $0.4 \pm 0.1$ \\
\hline \multirow[t]{6}{*}{$851 \# 95$} & TI-208 & & $<0.3$ \\
\hline & $\mathrm{Bi}-214$ & & $<0.3$ \\
\hline & $\mathrm{Bi}-212$ & & $<2.0$ \\
\hline & $A C-228$ & & $<0.3$ \\
\hline & $\mathrm{K}-40$ & & $<2.0$ \\
\hline & Cs-137 & & $<0.2$ \\
\hline Forestry Road \#357 & $\mathrm{Pb}-212$ & & $2.0 \pm 1.0$ \\
\hline Distance from site -4.4 miles & $\mathrm{Pb}-214$ & & $2.0 \pm 1.0$ \\
\hline Distance from Hwy 64 - & TI-208 & & $0.5 \pm 0.1$ \\
\hline 4.4 miles & $\mathrm{Bi}-214$ & & $0.8 \pm 0.2$ \\
\hline \multirow[t]{4}{*}{$1 \mathrm{ft}$. depth soil at windmill } & $\mathrm{Bi}-212$ & & $<1.0$ \\
\hline & $A C-228$ & & $<0.2$ \\
\hline & $K-40$ & & $32 \pm 5$ \\
\hline & Cs-137 & & $<0.1$ \\
\hline
\end{tabular}


TABLE 5 (Continued)

Gamma Emitting Isotopes in Site Samples

\section{Sample Identification}

Forestry Road \#357

Distance from site -4.4 miles

Distance from Hwy 64 -

4.4 miles

$2 \mathrm{ft}$. depth soil at windmill

$1 \mathrm{ft}$. depth grid

West 1 North 0 , Hole \#1

$4 \mathrm{ft}$. depth, Hole \#24

$5 \mathrm{ft}$. depth, Hole \#1

grid West 1 - North 0
Nuclide

$\mathrm{Pb}-212$

$\mathrm{Pb}-214$

TI-208

Bi-214

$\mathrm{Bi}-212$

Ac-228

K-40

Cs-137

Pb-212

$\mathrm{Pb}-214$

TI-208

Bi-214

Bi-212

Ac-228

K-40

Cs-137

Pb-212

$\mathrm{Pb}-214$

TI-208

Bi-214

Bi-212

Ac-228

K-40

Cs-137

Pb-212

$\mathrm{Pb}-214$

TI-208

Bi-214

Bi-212

Ac-228

K-40

Cs-137

$$
\begin{array}{cc}
\mathrm{pCi} / 1 \pm 2 \sigma & \mathrm{pCi} / \mathrm{g} \pm 2 \sigma \\
0.7 & \pm 0.2 \\
0.4 \pm 0.2 & \\
& <0.3 \\
0.6 \pm 0.2 & \leq 2.0 \\
& <0.3 \\
20 & \pm 4 \\
& <0.2
\end{array}
$$

$$
\begin{aligned}
0.7 & \pm 0.2 \\
0.7 & \pm 0.2 \\
& <0.4 \\
0.6 & \pm 0.2 \\
& <1.0 \\
& <0.3 \\
41 & \pm 6 \\
< & 0.2
\end{aligned}
$$

$$
\begin{gathered}
3.0 \pm 1.0 \\
2.0 \pm 1.0 \\
1.2 \pm 0.4 \\
0.4 \pm 0.2 \\
<2.0 \\
<0.3 \\
41 \pm 10 \\
<0.2
\end{gathered}
$$

$$
\begin{gathered}
0.9 \pm 0.2 \\
<0.2 \\
<0.2 \\
0.2 \pm 0.1 \\
<1.0 \\
<0.2 \\
10 \pm 2 \\
<0.1
\end{gathered}
$$


TABLE 6

Environmental Vegetation Sample Results

\section{Vegetation Samples}

Collection

$$
\text { Date }
$$

$9 / 20 / 78$

$9 / 20 / 78$

$9 / 21 / 78$

$9 / 21 / 78$

$9 / 21 / 78$

$9 / 21 / 78$

\section{Location}

S. Side of Road

N. Side of Road

Red Tank Area

Separator Area

Stack Area

Profile Hole \#16
Total Tritium*

$\mathrm{pCi} / \mathrm{ml}$ Water

$$
\begin{aligned}
& 2.8 \pm 0.5 \\
& <3.2 \pm 0.5 \\
& 10.4 \pm 0.3 \\
& 7.7 \pm 0.3 \\
& 470 \pm 2.6 \\
& 7.2 \pm 0.6
\end{aligned}
$$

* Free water and Organically bound 
TABLE 7

\section{List of Barrels \& Contents Sent to NTS}

\begin{tabular}{|c|c|c|c|c|c|}
\hline $\begin{array}{l}\text { Barrel } \\
\text { No. }\end{array}$ & Contents & $\stackrel{{ }^{3} \mathrm{H}}{\text { Concentration }}$ & $\begin{array}{c}\text { Est. } \\
\text { Weight }\end{array}$ & $\begin{array}{l}\text { Assumed } \\
\text { - Moisture } \\
\text { by Weight }\end{array}$ & $\begin{array}{l}\text { Estimated } \\
\text { Total } \\
\text { Activity }\end{array}$ \\
\hline 1 & $\begin{array}{l}\text { Dry bottom sludge } \\
\text { from Red Tank }\end{array}$ & $38,000 \mathrm{pCi} / \mathrm{ml}$ & 400 & 10 & $0.69 \mathrm{mCi}$ \\
\hline 2 & $\begin{array}{l}\text { McCullough wire } \\
\text { line approximately } \\
5000 \text { ' braided }\end{array}$ & $\begin{array}{c}1316 \mathrm{pCi} / 100 \mathrm{~cm}^{2} \\
\text { Swipe }\end{array}$ & 100 & 0 & $2.7 \times 10^{-5} \mathrm{mCi}$ \\
\hline 3 & $\begin{array}{l}\text { El Paso wire line } \\
\text { 20,000'; old wire } \\
\text { line - solid }\end{array}$ & $<$ LLD & 100 & 0 & 0 \\
\hline 4 & $\begin{array}{l}\text { Trash, insulation } \\
\text { pipe, wire, etc. }\end{array}$ & $<$ LLD & 50 & 0 & 0 \\
\hline 5 & $\begin{array}{l}\text { Sump sludge; } 2 \text { gas } \\
\text { filters }\end{array}$ & $433 \mathrm{pCi} / \mathrm{ml}$ & 300 & 10 & $6.5 \times 10^{-2} \mathrm{mCi}$ \\
\hline 6 & $\begin{array}{l}\text { Soil \& sump sludge; } \\
\text { cement and diatoma- } \\
\text { ceous earth }\end{array}$ & $660 \mathrm{pCi} / \mathrm{ml}$ & 400 & 10 & $1.3 \times 10^{-2} \mathrm{mCi}$ \\
\hline 7 & Lab Waste & $<$ LLD & 200 & 0 & 0 \\
\hline 8 & $\begin{array}{l}\text { Drilling Debris; } \\
\text { milling chips }\end{array}$ & $<$ LLD & 500 & 0 & 0 \\
\hline 9 & $\begin{array}{l}\text { Decon sump sludge } \\
\text { with drying agent; } \\
\text { cement and water }\end{array}$ & $21 \mathrm{pCi} / \mathrm{ml}$ & 400 & 10 & $8 \times 10^{-7} \mathrm{mCi}$ \\
\hline \multirow[t]{2}{*}{10} & 1250 scintillation & $21 \mathrm{pCi} / \mathrm{ml}$ & 300 & 10 & $6 \times 10^{-7} \mathrm{mCi}$ \\
\hline & & & TOTAL: & & $0.77 \mathrm{mCi}$ \\
\hline
\end{tabular}

(LLD $2 \mathrm{pCi} / \mathrm{ml} @ 3 \sigma$ counting error for Tritium) 


\section{TABLE 8}

\section{Gasbuggy Site Clearance Criteria}

\section{Surface Water}

Tritium

$300 \mathrm{pCi} / \mathrm{ml}$

\section{Buildings, Equipment \& Materials}

Tritium (Non-removable)

Tritium (Removable)

$5,000 \mathrm{pCi} / 100 \mathrm{~cm}^{2}$

$1,000 \mathrm{pCl} / 100 \mathrm{~cm}^{2}$

\section{Soil}

Tritium only

$30,000 \mathrm{pCi} / \mathrm{ml}$

Soil Moisture

Beta-Gamma (Including worldwide fallout)

$0.05 \mathrm{mrad} / \mathrm{hr}$

Beta-Gamma

(Measured at $1 \mathrm{~cm}$ )

Reference:

DOE Appendix 0524 Annex A Table 2 and ANSI 328-1976 (Table 1 of 2) and NVO-195 Project Gasbuggy Well Plugging and Site Restoration Plan Section V. 


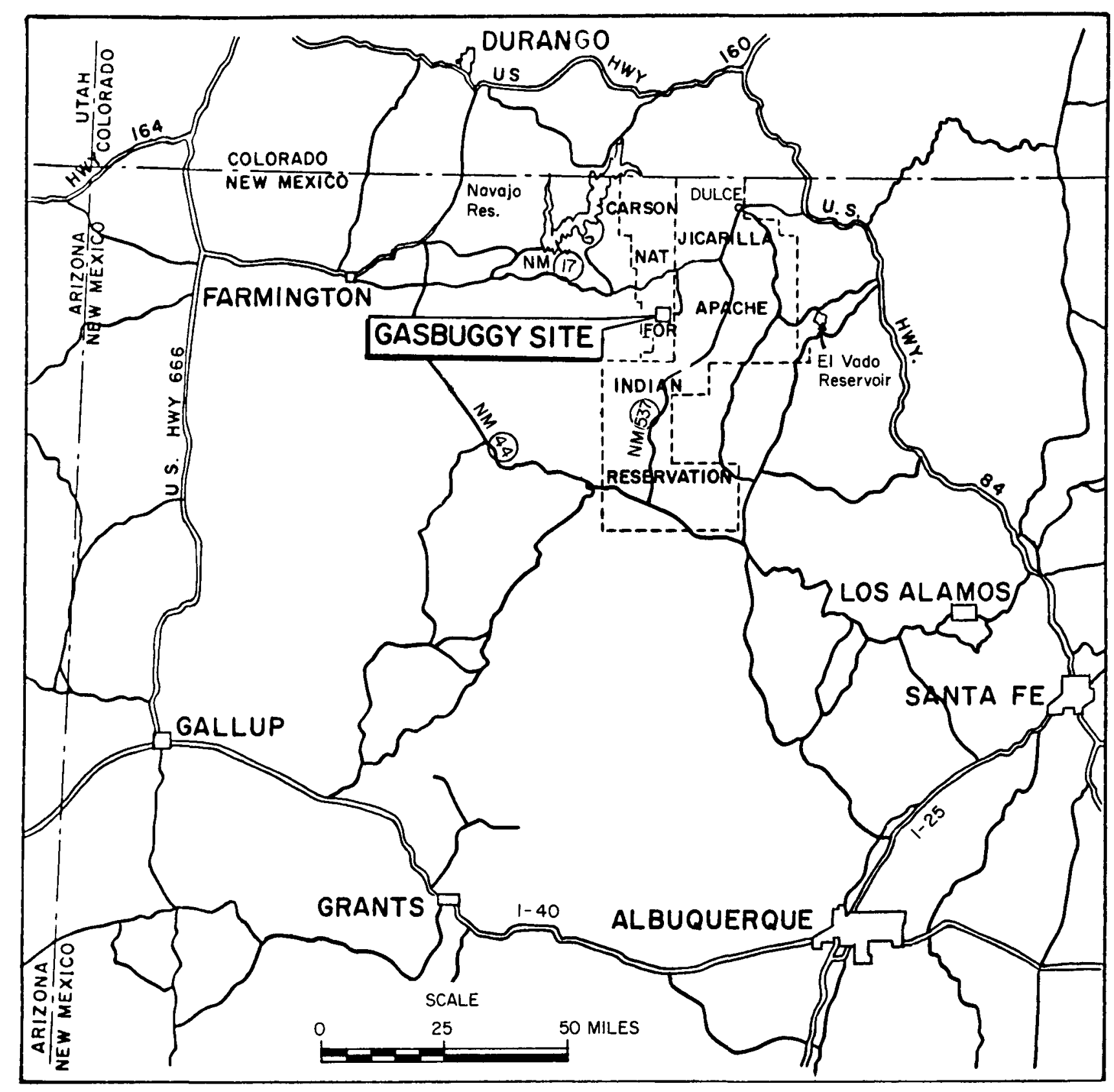

Figure 1 Project Gasbuggy Site Location Map 


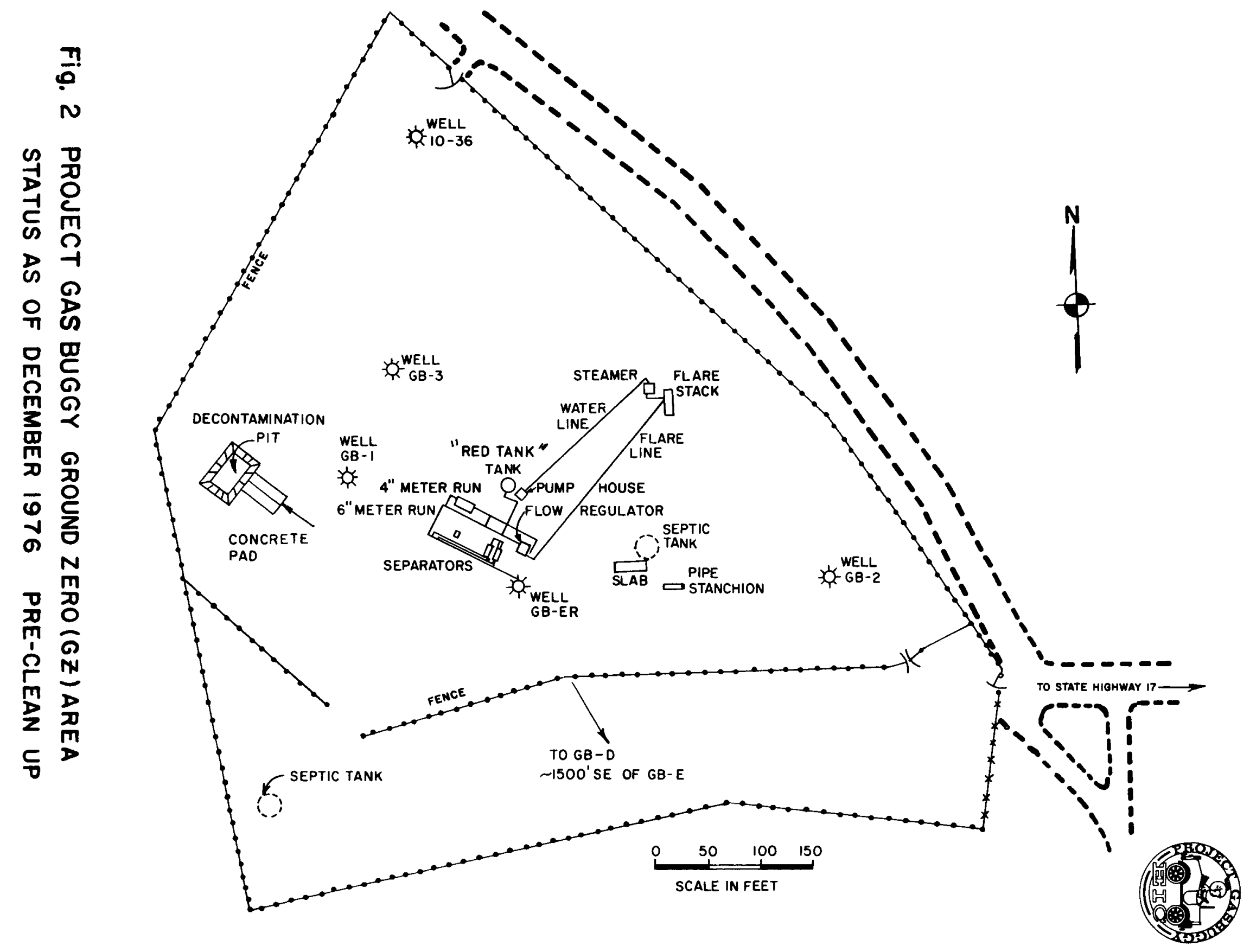




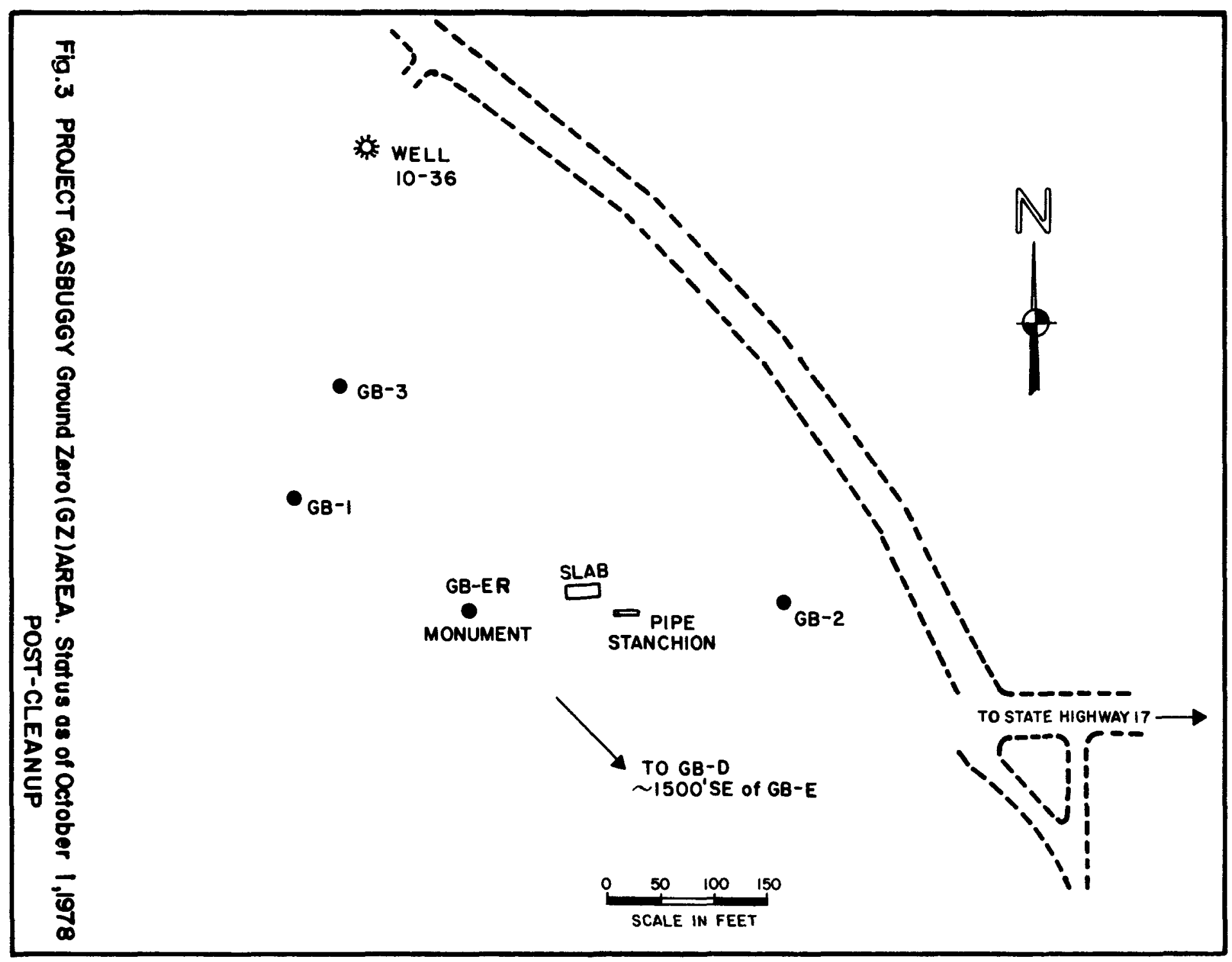




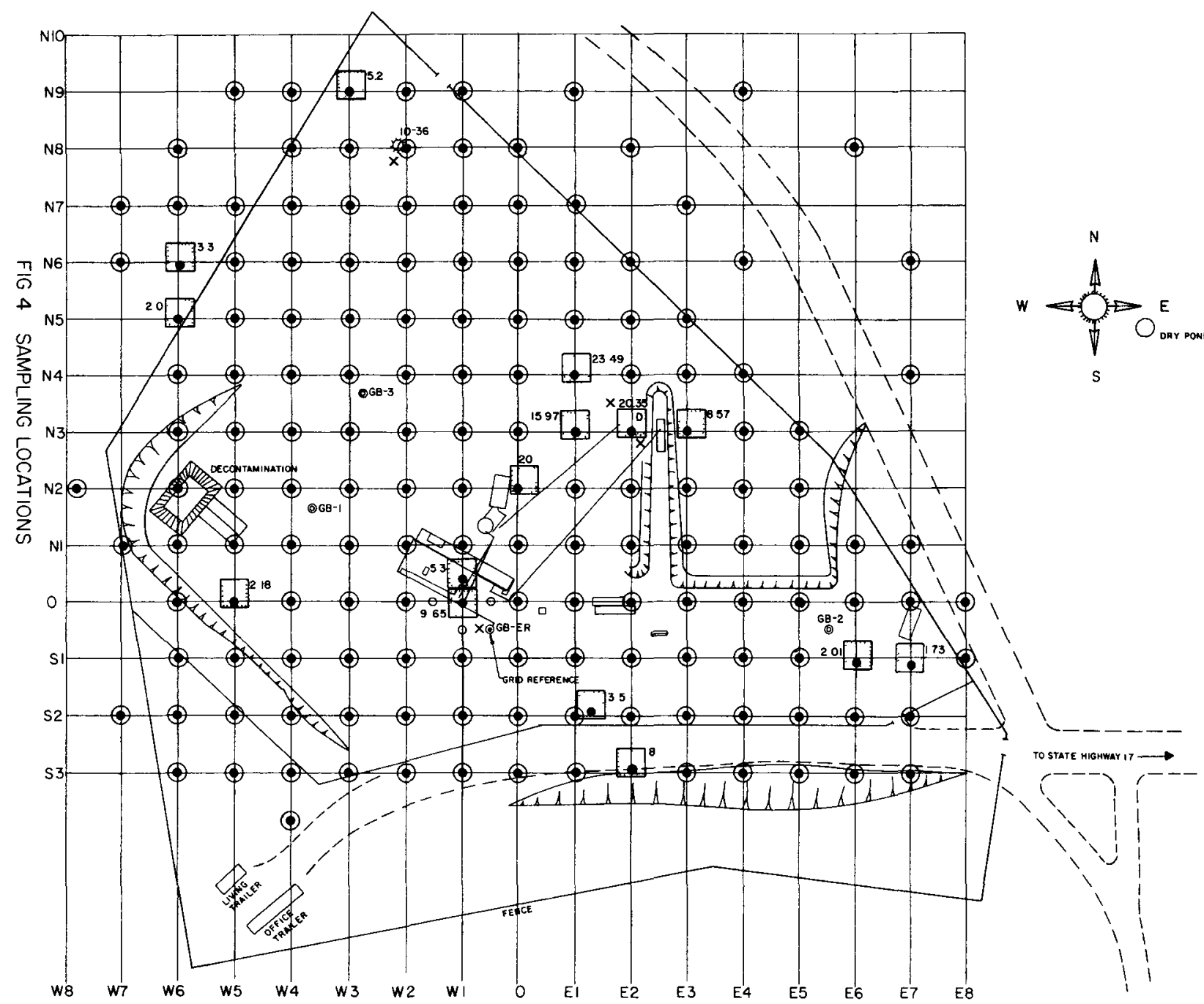

$\times$ mOLECULAR SEIVE MOISTURE COLLECTOR LOCATIONS

O <LLD

$x \times x\left[\begin{array}{l}\text { pCi/mt } \\ \text { sort MOISTURE }\end{array}\right.$

Oo soll sample locations

- Bysurver points

SCALE $=50$ OH GRID (SQuaAE)

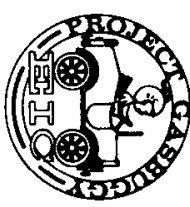




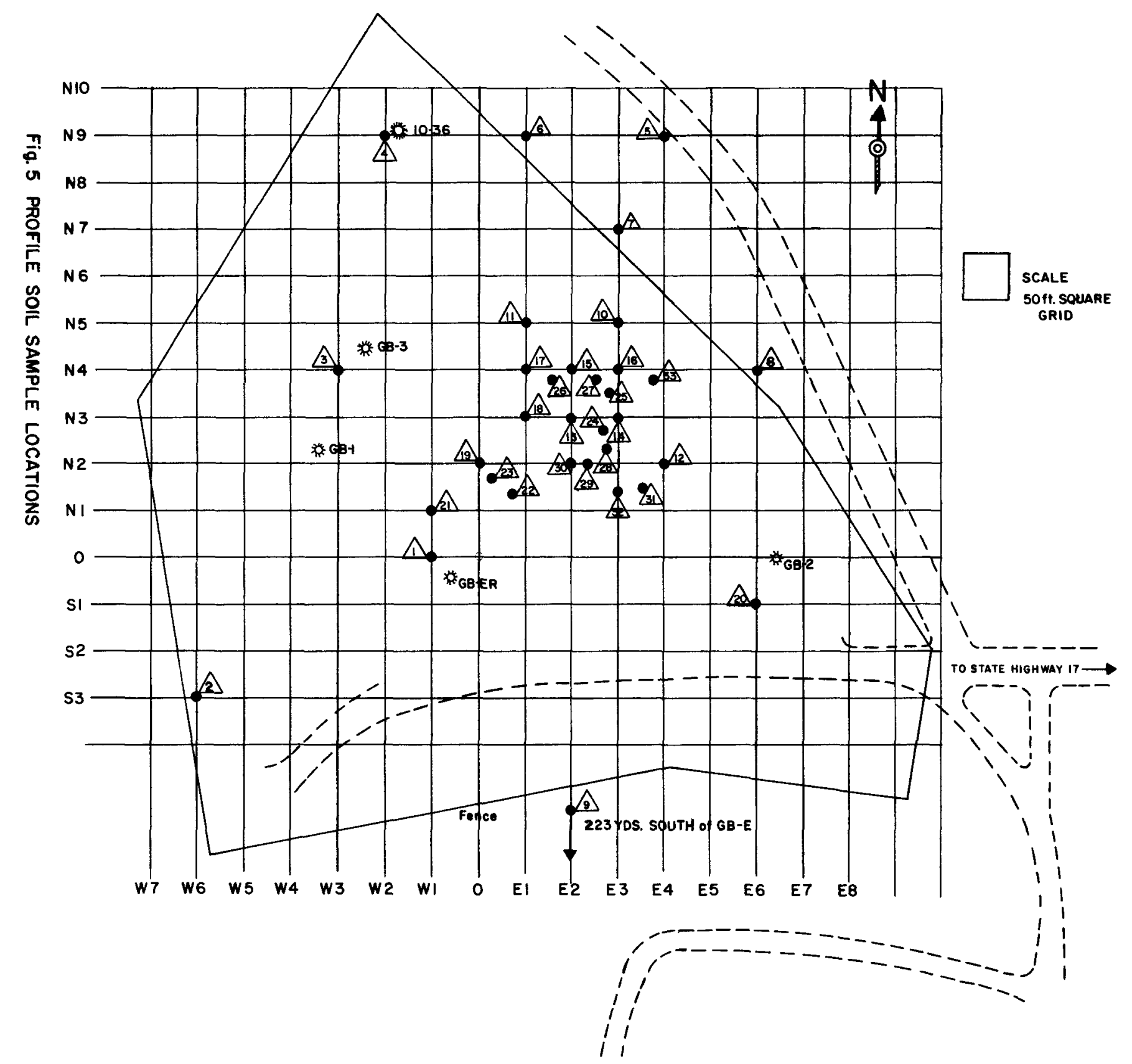




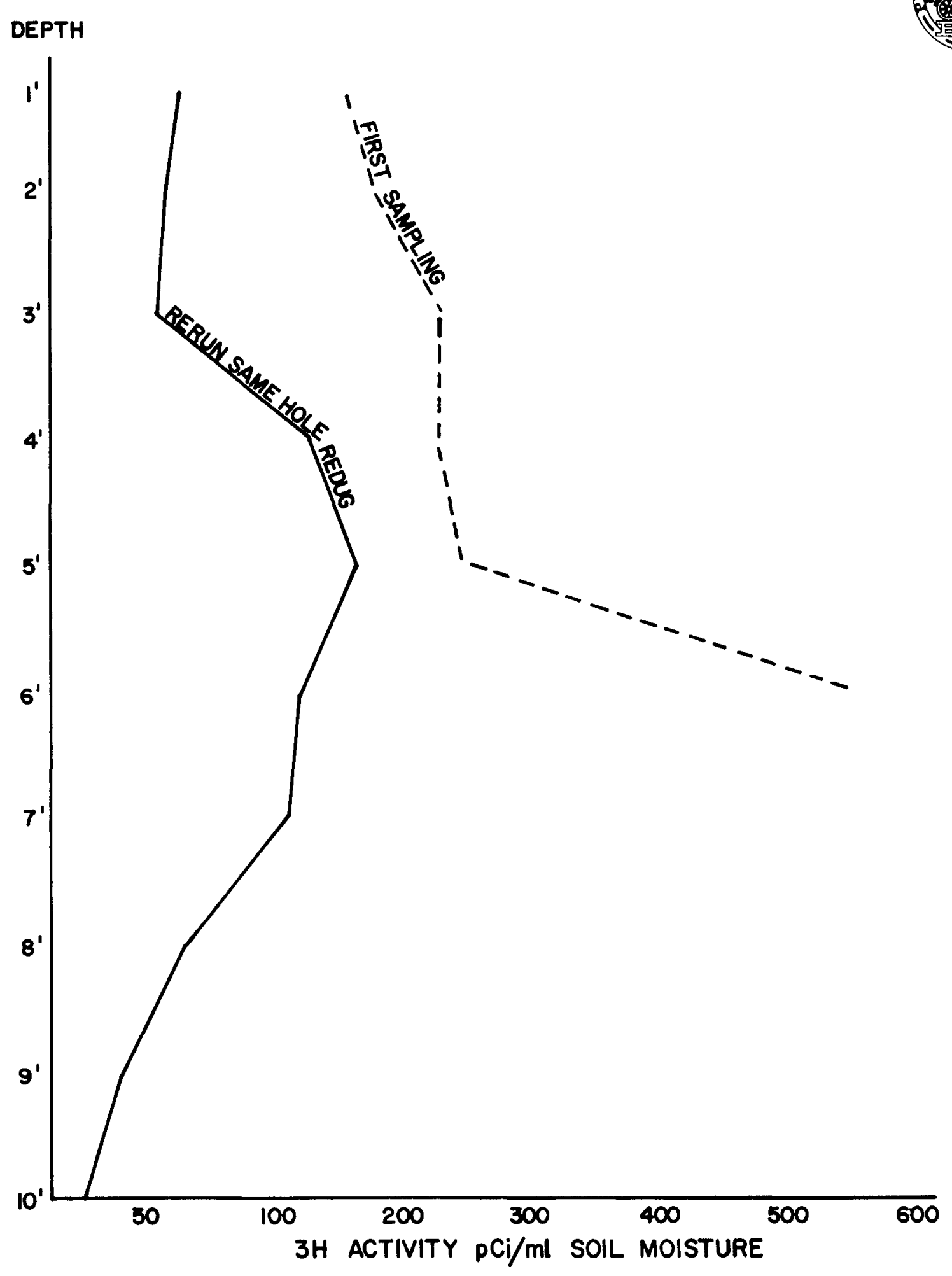

FIG. 6 TRITIUM ACTIVITY VS DEPTH FOR PROFILE HOLE I WI, 


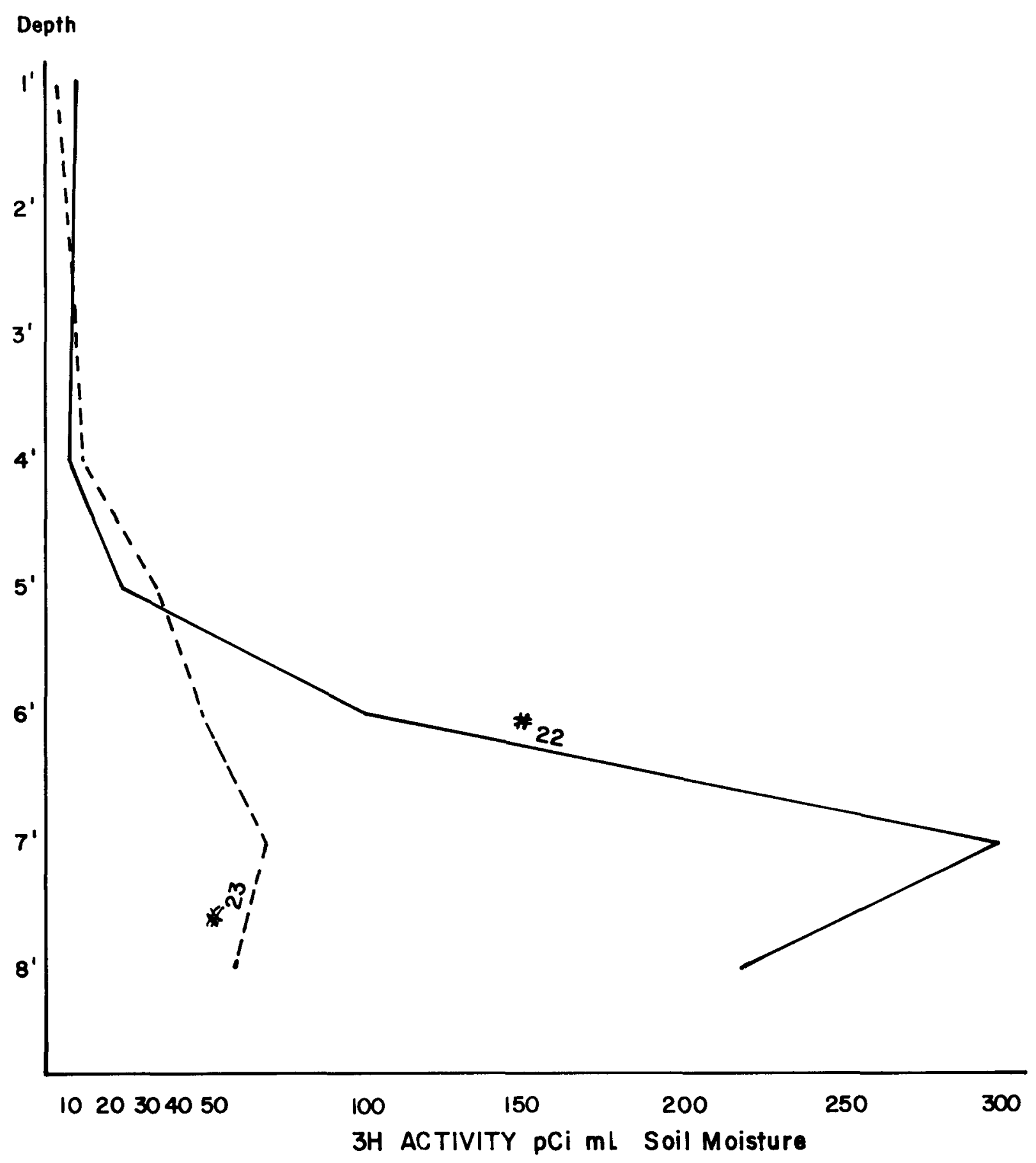

FIG.7 TRITIUM ACTIVITYYS DEPTH FOR PROFILE HOLES 22 EINI IO'N $18^{\prime} \mathrm{W}$ $23 E I N I 16^{\prime} N 33^{\prime} W$ 


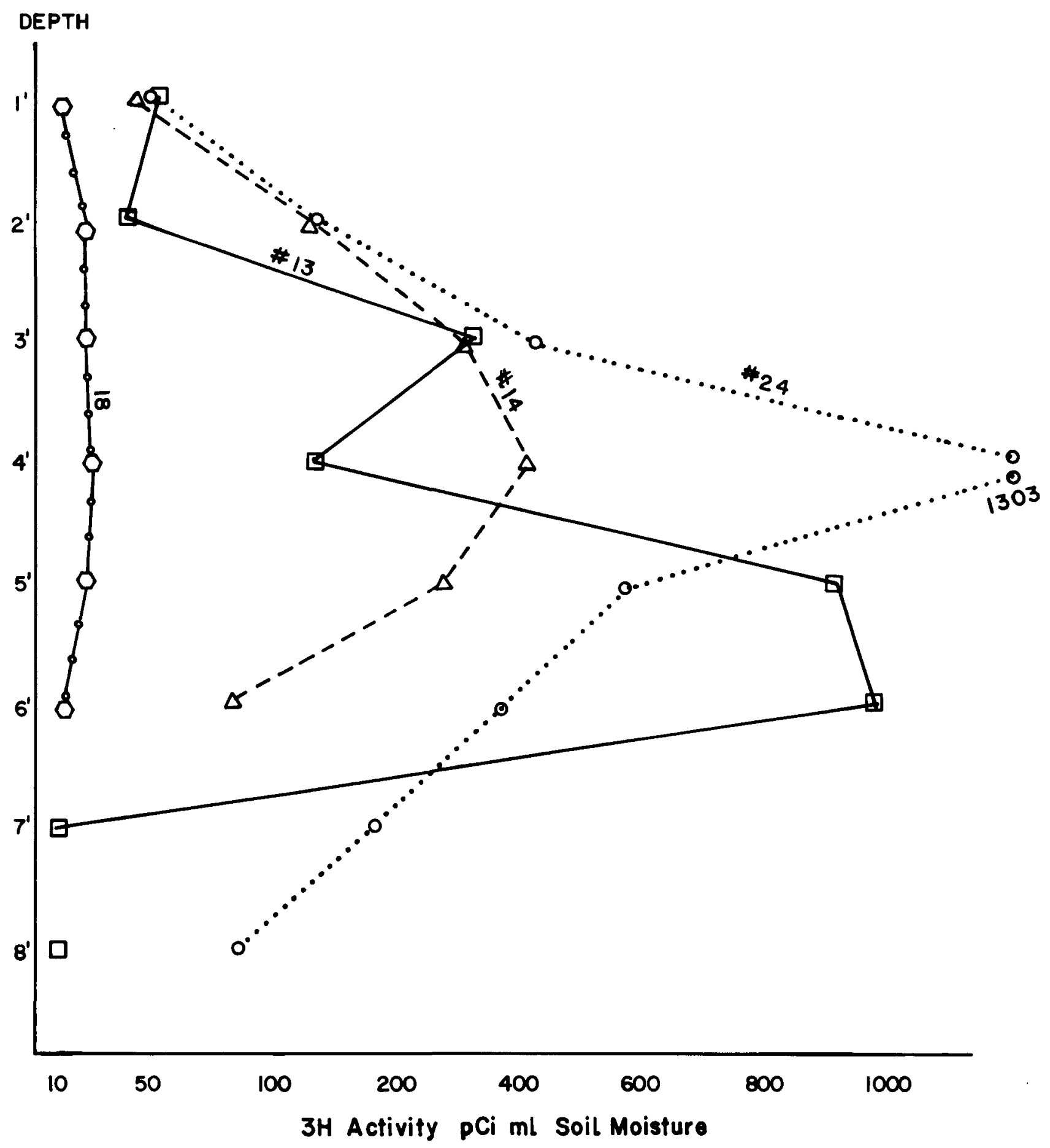

FIG.8 TRITIUM ACTIVITY VS DEPTH FOR PROFILE HOLES SOUTH OF FLARE STACK 

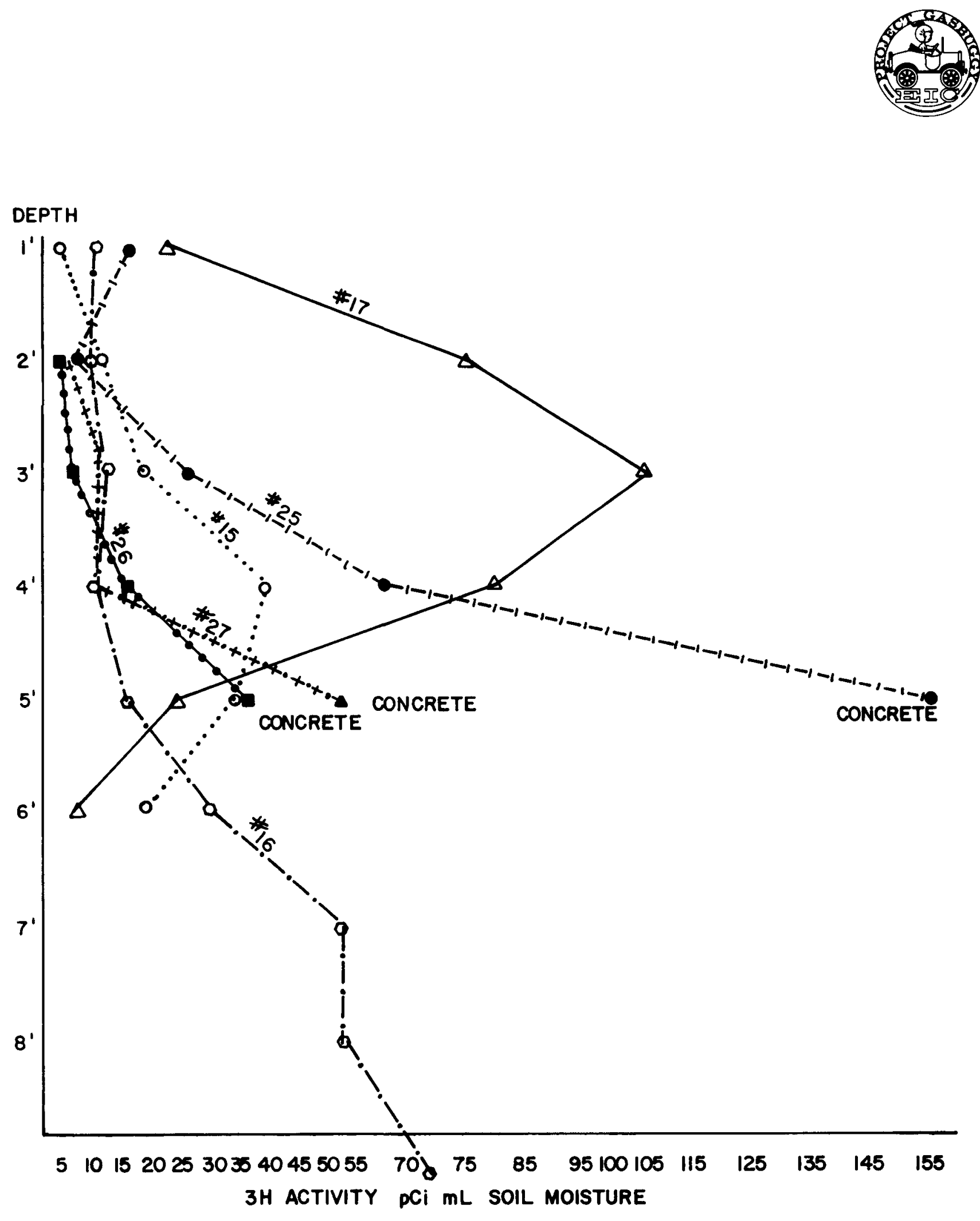

FIG.9 TRITIUM ACTIVITY VS DEPTH FOR PROFILE HOLES NORTH OF FLARE STACK 

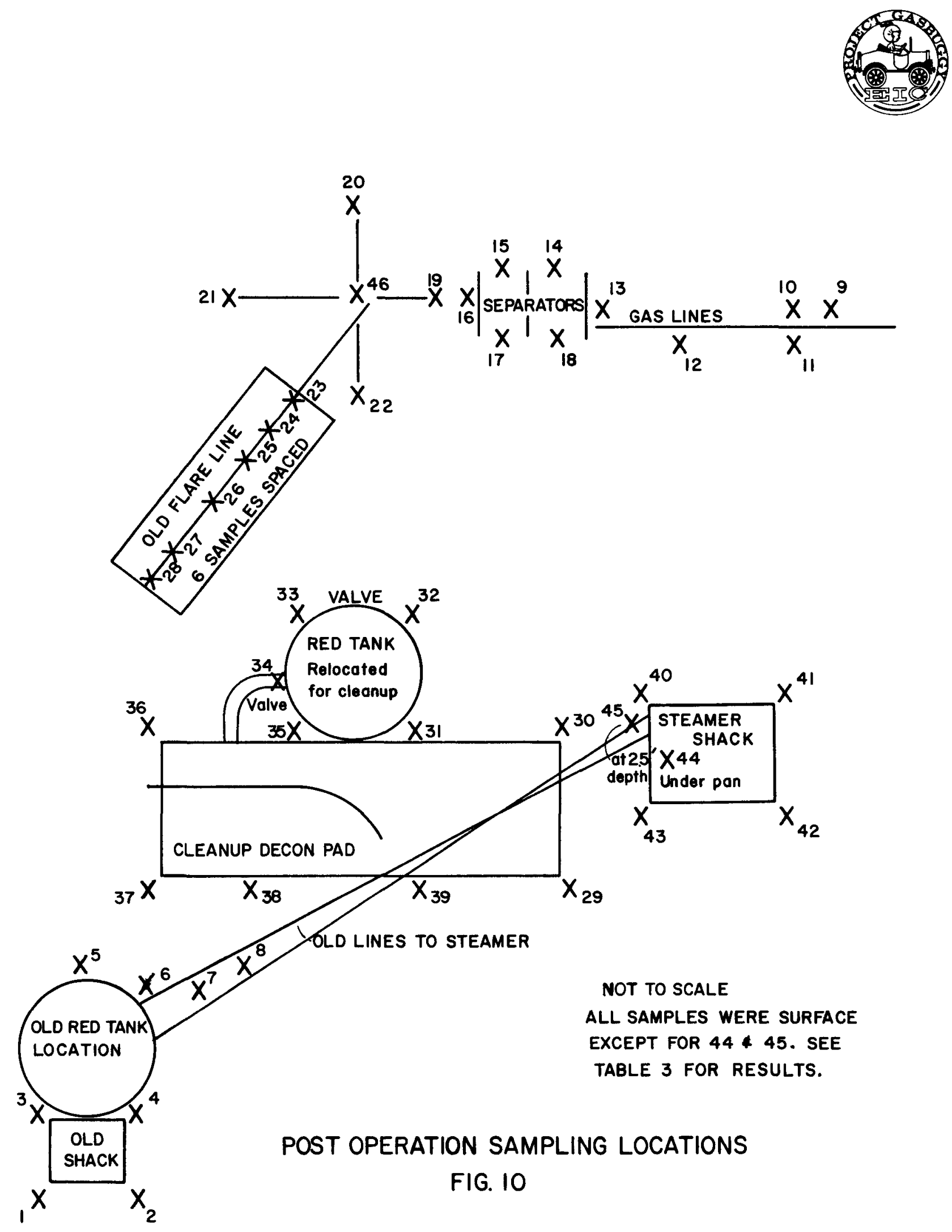


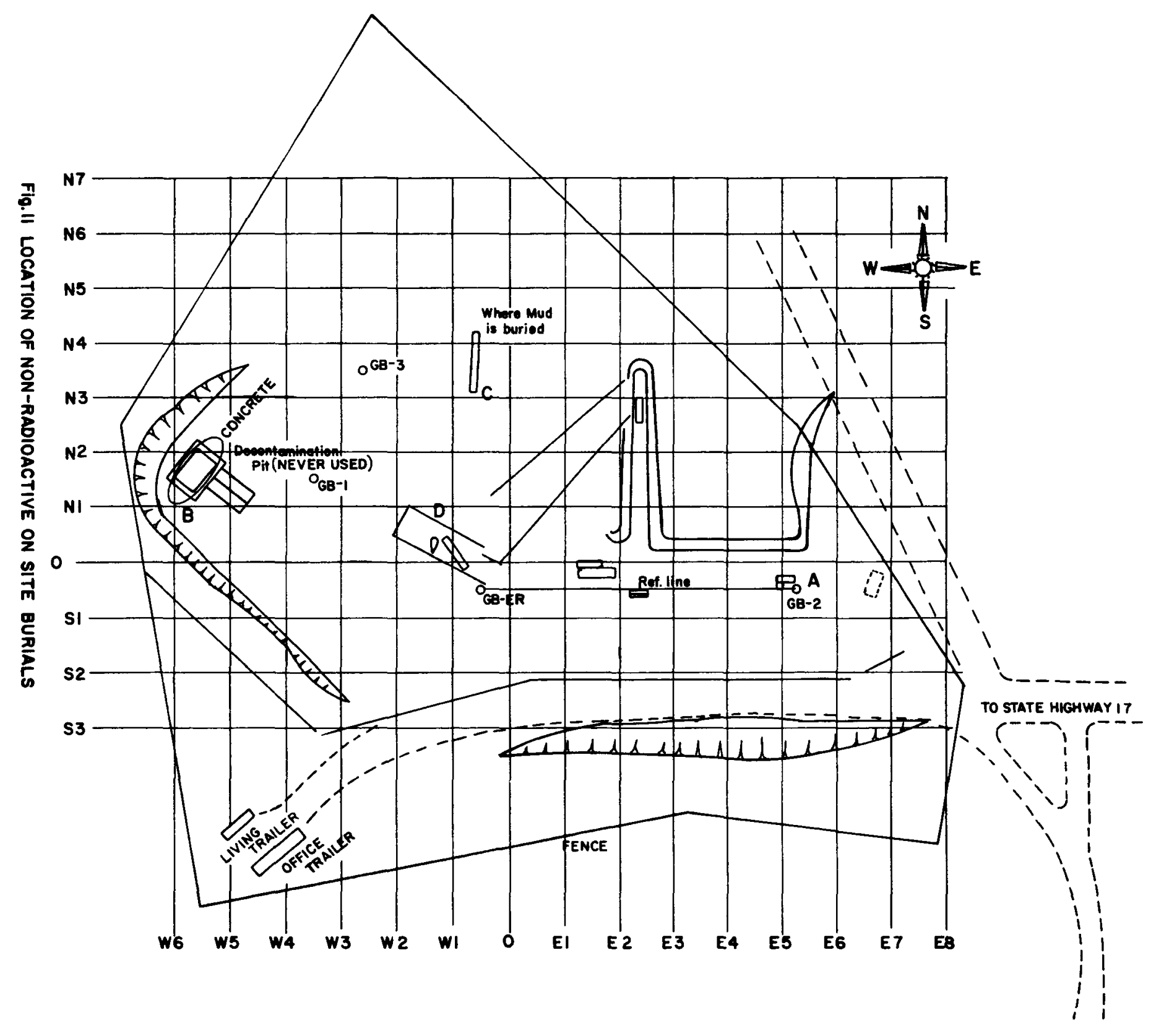




\title{
DISTRIBUTION LIST
}

\author{
R.H. Hertzberg, Division of Fossil Fuel Extraction \\ J.K. Bratton, MA, HO (2) \\ D.C. Ward, Division of Fossil Fuel Extraction \\ A. Crawley, Division of Fossil Fuel Extraction \\ M.E. Gates, Manager, NV \\ L. Silverstrom, Chief Cousel, NV \\ R.W. Taft, AMPE\&B, NV \\ R.D. Duncan, AMA, NV \\ R.W. Newman, AMO, NV \\ D. Jackson, OPA, NV (2) \\ E.M. Douthett, Dir., P\&LSD, NV (2) \\ P.J. Mudra, Dir., OSD, NV \\ J.B. Cotter, Dir., E\&EAD, NV (5) \\ B.W. Church, Rad. Br., NV (3) \\ R.R. Loux, OPA, NV (20) \\ D.N. Canfield, EI Paso Natural Gas Co., El Paso, TX \\ C.E. Matthews, El Paso Natural Gas Co., Farmington, NM (2) \\ J. Crellin, Forest Supervisor, Carson National Forest, USFS, Taos, NM (2) \\ J. Long, USGS, Durango, CO \\ A.E. Doles, Eberline, Santa Fe, NM (2) \\ R.H. Ashlock, F\&S, Las Vegas, NV (3) \\ W.R. Woodruff, LLL, Livermore, CA (5) \\ L.B. Ballou, LLL, Livermore, CA \\ F. Holzer, LLL, Livermore, CA \\ J. Cramer, LLL, Livermore, CA \\ C. Costa, EPA-EMSL, Las Vegas, NV \\ TIC, Oak Ridge, TN (2) \\ T. Wolff, State of New Mexico (5) \\ S. Elliott, OS\&H, NV \\ E. Campbell, NSD, NV \\ W.J. McCool, OES, Ha (2) \\ A.J. Whitman, ECT, $\mathrm{Hq}(2)$ \\ P.K. Fitzsimmons, OSD, NV (2) \\ A.E. Bicker REECO, Mercury, NV \\ E. Chew, INEL, ID
}

